\title{
The Political Force of Musical Actants: Grooves, Pleasures, and Politics in Havana D'Primera's 'Pasaporte' Live in Havana
}

\author{
KJETIL KLETTE BØHLER
}

\begin{abstract}
Drawing upon Rancière's argument that aesthetics instigates politics, Latour's rethinking of agency as relational, and Ortiz's work on Afro-Cuban music aesthetics, this article explores how the experience of aesthetic pleasure in Cuban timba grooves makes politics audible and affective in novel ways. Through a combination of ethnographic and musical analyses of Havana D'Primera's performance of 'Pasaporte' live at Casa de la Música in 2010, it unpacks the political affordances of calland-response singing and polyrhythmic timba grooves among participating listeners in Havana. In contrast to the recurrent tendency to exclude musical details from research into the politics of music, this article suggests that engaging grooves and catchy melodies do important political work as musical actants by creating affective communities and new expressions of political critique. The concept of musical actants serves as a lens through which to view these pregnant interactions between rhythmic, melodic, social, and political meanings in time.
\end{abstract}

I always try to think in terms of horizontal distributions, combinations, between systems of possibilities, not in surface and substratum. Whereas one searches for the hidden beneath the apparent, a position of slavery is established. I have tried to conceive of a topography that does not presuppose this position of mastery. It is possible, from any moment, to try to reconstruct the conceptual network . . that causes a painting or a piece of music to make an impression that causes reality to appear transformable or inalterable. This is the main theme of my research. ${ }^{1}$

Central to Jacques Rancière's rethinking of the politics of aesthetics is his movement away from the Marxist tradition's distinction between base and superstructure and view that

Email: kjetil.bohler@oslomet.no

I want to thank the anonymous reviewers for constructive critiques that helped me improve the article. I also want to thank Robin Moore, Anne Danielsen, Robert Hatten, Jocelyne Guilbault, Chris Stover, David García, Christopher Washburne, and John Street, among others, for giving fruitful comments to earlier versions of the present article. In addition, I would like to thank Jacques Rancière and Frédérique Aït-Touati for providing vital feedback on earlier versions of the paper that has substantially shaped the present article.

1 Jacques Rancière, The Politics of Aesthetics (London: Bloomsbury, 2013), 49-50. 
politics operates as a hidden power structure outside the aesthetic experience. Instead, Rancière frames politics as the way in which aesthetic experiences create new subjectivities and ways of being together that disrupt 'what is common to the community' ${ }^{2}$ in a social or political order. Inspired by Rancière's arguments, in tandem with Bruno Latour's rethinking of agency as relational and aesthetics as transformative, ${ }^{3}$ this article explores how experiences of pleasure in Cuban timba grooves make politics audible and affective in novel ways. Through a combination of ethnographic and musical analyses of Havana D'Primera's performance of 'Pasaporte' live at Casa de la Música in 2010, it unpacks the political affordances of call-and-response singing and polyrhythmic timba grooves for participating listeners in Havana. ${ }^{4}$ In the last decade, 'Pasaporte', which was released officially in 2012, has been among the most popular timba hits in Cuba. This study looks at its rise to popularity in Havana starting two years before its release in the context of the sheer political force of musical grooves in contemporary Cuba. Unlike existing studies of the politics of music which tend to ignore musical details, this article demonstrates how engaging grooves and catchy melodies do important political work by creating affective communities and new expressions of critique. In doing so, it draws attention to how specific musical structures afford particular modes of affective engagement, social organization, and political critique.

\section{Scholarship on the politics of music}

Most studies on the politics of music locate the political in the realm of musical contexts, not in musical texts (i.e., the grooves, harmonies, and melodies). ${ }^{5}$ Several studies look at how music mediates social and political meanings within the larger cultural web of symbolic representations, ${ }^{6}$ or at how the political meanings of music are discursively constructed via

2 Rancière, Politics of Aesthetics, 12.

3 I draw particularly on Latour's understanding of agency as relational in the context of his critique of the social (see Bruno Latour, Reassembling the Social: A Guide to Actor-Network Theory (Cambridge: Cambridge University Press, 2005), 74-87); his understanding of actants (see Bruno Latour, 'On Actor-Network Theory: A Few Clarifications Plus More Than a Few Complications', Soziale welt 47/4 (1996), 7; and Bruno Latour, 'Technology Is Society Made Durable', Sociological Review 38/1 (1990), 105-22); and his recent work on aesthetic experience (see Bruno Latour, An Inquiry into Modes of Existence (Cambridge, MA: Harvard University Press, 2013), 371-3).

4 Timba is a virtuosic style of Cuban popular dance music sometimes described as salsa cubana which is characterized by dense polyrhythmic grooves modelled on syncopation. See, for example, Vincenzo Perna, Timba: The Sound of the Cuban Crisis (London: Routledge, 2017), and Robin D. Moore, Music and Revolution: Cultural Change in Socialist Cuba (Berkeley: University of California Press, 2006), 197-250. Since their first album, Haciendo Historia (2009), Havana D'Primera, under the leadership of singer, composer, and trumpet player Alexander Abreu, has been among the most popular timba bands in Cuba.

5 John Street, Music and Politics (New York: John Wiley and Sons, 2013), 42-5.

6 See, for example, Keith Negus, Popular Music in Theory (Middletown: Wesleyan University Press, 1996), 15; Dick Hebdige, Subculture: The Meaning of Style (New York: Routledge, 1979); Antoine Hennion, The Passion for Music: A Sociology of Mediation (New York: Routledge, 2017); Louise Meintjes, 'Paul Simon's Graceland, South Africa, and the Mediation of Musical Meaning', Ethnomusicology 34/1 (1990); and Jocelyne Guilbault, Governing Sound: The Cultural Politics of Trinidad's Carnival Musics (Chicago: University of Chicago Press, 2007). 
everyday talk, ${ }^{7}$ newspapers, ${ }^{8}$ and cultural policy documents. ${ }^{9}$ Recent studies on interactions between affect and politics in ethnomusicology have challenged these distinctions by showing how musical and sonic texts and contexts interact in complex ways within cultural practice through rich ethnographies. ${ }^{10}$ However, by representing such interactions ethnographically these studies tell us little about the political force of musical structures. The affective surplus value of singing a political argument in a particular way, and the ways in which that musical structure invite people to dance and sing along, is often left out of the equation in favour of broader anthropological interpretations of how sound matter as aesthetic, social, and political experience rooted in particular historical contexts. Except for the important work by Noriko Manabe and Barry Shank, few studies integrate in-depth political, social, and musical analysis in explorations of how affective politics manifest as specific organizations of musical sound. ${ }^{11}$

7 See, for example, Simon Frith, Performing Rites: On the Value of Popular Music (Oxford: Oxford University Press, 1998) and Tia DeNora Music in Everyday Life (Cambridge: Cambridge University Press, 2000).

8 See, for example, Alejandro L. Madrid and Robin D. Moore, Danzón: Circum-Caribbean Dialogues in Music and Dance (Oxford: Oxford University Press, 2013), 79-115 and Ronald Radano, 'Hot Fantasies: American Modernism and the Idea of Black Rhythm', in Music and the Racial Imagination, ed. Ronald Radano and Phillip Bohlman (Chicago: University of Chicago Press, 2000), 459-73.

9 See, for example, Kelly Askew, Performing the Nation: Swahili Music and Cultural Politics in Tanzania (Chicago: University of Chicago Press, 2002) 196-280; Moore, Music and Revolution, 80-107.

10 See, for example, Benjamin Tausig, Bangkok Is Ringing: Sound, Protest, and Constraint (New York: Oxford University Press, 2019), 1-7; Matt Sakakeeny, Roll with It: Brass Bands in the Streets of New Orleans (Durham: Duke University Press, 2013); 13-19; Ellen Gray, Fado Resounding: Affective Politics and Urban Life (Durham: Duke University Press, 2013); 129-37; Marié Abe, Resonances of Chindon-ya: Sounding Space and Sociality in Contemporary Japan (Middletown: Wesleyan University Press, 2018); 135-92; Denise Gil, Melancholic Modalities: Affect, Islam, and Turkish Classical Musicians (New York: Oxford University Press, 2017), 183-5; Ana Hofman, 'The Affective Turn in Ethnomusicology', Muzikologija 18 (2015); Ana Hofman, 'Disobedient: Activist Choirs, Radical Amateurism, and the Politics of the Past after Yugoslavia', Ethnomusicology 64/1 (2020), 90-1; and Luis-Manuel Garcia, 'Feeling the Vibe: Sound, Vibration, and Affective Attunement in Electronic Dance Music Scenes', Ethnomusicology Forum (2020).

11 See, for example, the following by Noriko Manabe, The Revolution Will Not Be Televised: Protest Music after Fukushima (New York: Oxford University Press, 2015), 'Women's March Colloquy-Chants of the Resistance: Flow, Memory, and Inclusivity', Music and Politics, 13/1 (2019), and 'We Gon' Be Alright? The Ambiguities of Kendrick Lamar's Protest Anthem', Music Theory Online 25/1 (2019); and Barry Shank's book The Political Force of Musical Beauty (Durham: Duke University Press, 2014) and his article 'The Political Agency of Musical Beauty', American Quarterly, 63/3 (2011). Other relevant studies that integrate in-depth aesthetic and musical analysis in interpretations of politics include João Pedro Cachopo, Patrick Nickleson, and Chris Stover, Rancière and Music (Edinburgh: Edinburgh University Press, 2020); Eric Drott, Music and the Elusive Revolution: Cultural Politics and Political Culture in France, 1968-1981 (Berkeley: University of California Press, 2011); Gavin Steingo, Kwaito's Promise: Music and the Aesthetics of Freedom in South Africa (Chicago: University of Chicago Press, 2016); Eduardo Herrera 'Masculinity, Violence, and Deindividuation in Argentine Soccer Chants: The Sonic Potentials of Participatory Sounding-in-Synchrony', Ethnomusicology 62/3 (2018); Kjetil Klette Bøhler, 'Musical Politics in the Cuban Police Order', in Rancière and Music, ed. Cachopo, Nickleson, and Stover; Kjetil Klette Bøhler, 'Theorizing Musical Politics through Case Studies: Feminist Grooves against the Temer Government in Today's Brazil', International Journal of Gender, Science and Technology 9/2 (2017); Kjetil Klette Bøhler, “Somos la mezcla perfecta, la combinación más pura, cubanos, la más grande creación”: Grooves, Pleasures, and Politics in Today’s Cuba', Latin American Music Review 37/2 (2016). 
Instead, there is still a tendency to locate the political in music's different contexts, discourses, and mediations. $^{12}$

This view has also influenced scholarship on the politics of Cuban popular music. For example, several scholars have described Cuban punk, rock and hip-hop as cultural expressions of political critique inspired by theories and methods from anthropology, sociology, and cultural studies. ${ }^{13}$ Other scholars, drawing on similar interpretive frames, have elaborated on how the politics of race and gender is enacted in Cuban timba and reggaeton and how political critique is articulated metaphorically in contemporary Cuban trova. ${ }^{14}$ While these studies tell us much about the politics of lyrics, and how Cuban music gained political meanings in particular cultural contexts, they tell us less about the ways in which sung words matter affectively and politically due to particular organizations of musical sound (e.g., catchy melodies and engaging grooves modelled on specific musical structures). Some exceptions to this trend include Robin Moore's book chapter 'Cuban dance music and the politics of fun' and

12 It is important to add that recent scholarship on music and mediation have widened the conceptual scope of mediation as a theoretical concept by also taking into account interactions between sonic objects and listening subjects. See, for example, Georgina Born and Andrew Barry, 'Music, Mediation Theories and Actor-Network Theory', Contemporary Music Review, 37/5-6 (2018), 447-52; Antoine Hennion, 'Music and Mediation', in The Cultural Study of Music, ed. Martin Clayton, Trevor Herbert, and Richard Middleton (London: Routledge, 2012), 82-6; and Antoine Hennion and Stephen Muecke. 'From ANT to Pragmatism: A Journey with Bruno Latour at the CSI', New Literary History 47/2 (2016), 293-4. Still, few of these studies investigate how such interactions matter affectively and aesthetically as people's perception of particular musical structures.

13 For studies on Cuban hip-hop see, for example, Geoffrey Baker, Buena Vista in the Club: Rap, Reggaetón, and Revolution in Havana (Durham: Duke University Press, 2011), and ‘¡Hip Hop, Revolución! Nationalizing Rap in Cuba', Ethnomusicology 49/3 (2005); Tanya L. Saunders, Cuban Underground Hip Hop: Black Thoughts, Black Revolution, Black Modernity (Austin: University of Texas Press, 2015); Marc Perry, Negro Soy Yo: Hip Hop and Racialized Citizenship in Neoliberal Cuba (Durham: Duke University Press, 2016); and Sujatha Fernandes, 'Fear of a Black Nation: Local Rappers, Transnational Crossings, and State Power in Contemporary Cuba', Anthropological Quarterly 76/4 (2003). For studies on Cuban punk rock see, for example, Geoffrey Baker, 'Cuba Rebelión: Underground Music in Havana', Latin American Music Review 32/1 (2011) and Rubén López-Cano, 'Music and Post-Communist Subjectivities in Cuba', in Music and Youth Culture in Latin America: Identity Construction Processes from New York to Buenos Aires, ed. Pablo Vila (New York: Oxford University Press).

14 For work on race and gender in Cuban timba see, for example, Ariana Hernández-Reguant, 'Havana's Timba. A Macho Sound for Black Sex', in Globalization and Race: Transformations in the Cultural Production of Blackness, ed. Kamari Maxine Clarke and Deborah A. Thomas (Durham: Duke University Press; 2012); Umi Vaughan, Rebel Dance, Renegade Stance: Timba Music and Black Identity in Cuba (Michigan: University of Michigan Press, 2012). Rubén López-Cano, 'El chico duro de La Habana: Agresividad, desafío y cinismo en la timba cubana', Latin American Music Review, 28/1 (2007). It is important to underscore that López-Cano integrate in-depth musical analysis in his study of the relationship between music, gender, and blackness to a larger extent than the others. For work on how reggaeton articulates blackness and gendered politics and a new consumer culture see, for example, Nora Gámez Torres, 'Hearing the Change: Reggaeton and Emergent Values in Contemporary Cuba', Latin American Music Review 33/2 (2012) and Baker, Buena Vista in the Club. For studies on how contemporary forms of Cuban trova articulates political critique through complex metaphors see, for example, Robin D. Moore, 'Transformations in Cuban Nueva Trova, 1965-95', Ethnomusicology 47/1 (2003); Liliana Casanella Cué and Orestes Solís Yero, En defensa del texto (Santiago de Cuba: Editorial Oriente, 2004); and López-Cano, 'Music and Post-Communist Subjectivities in Cuba'. 
Vincenzo Perna's important book Timba. The Sound of the Cuban Crisis. ${ }^{15}$ However, while Moore and Perna integrate musical analysis in their social and political interpretations, they don't specify how specific organizations of musical sounds matter politically. As a consequence, it is unclear how the identified musical structures articulate political experience, and more broadly, whether they matter affectively at the level of political theory. Taken together, scholarship on the politics of Cuban music tends to situate the political beyond the musical inspired by theories and methods from the social sciences.

This is characteristic of scholarship on the politics of music more broadly, across countries and disciplines, and the following quote from Keith Negus' influential book Popular Music in Theory may illustrate:

One of the implications of what I have been arguing in this book is that we cannot locate the political meaning of music in any sound text. To search for the 'meaning' is probably a waste of time, and it might give more insight into how music communicates to follow the processes of change that occur as the music leaves its point of origins and connects with different bodies across a wide range of social and technological mediations. ${ }^{16}$

According to Negus, the social and political meanings of music cannot be found within traditional forms of musicological enquiry (e.g., musical analysis of sound texts coupled with in-depth aesthetic description). Instead, he suggests that theories and methods from anthropology, sociology, and cultural studies offer a better framework to study music's social and political meanings. Simon Frith argues along the same line in the chapter titled 'The Sociological Response' in Performing Rites, where he states: 'Our reception of music, our expectation from it, are not inherent in the music itself - which is one reason why so many musicological analyses of popular music miss the point: its object of study, the discourse text it constructs, is not the text to which anyone listens.' ${ }^{17}$

The 'music itself supplies a pole opposite that of its context for both Negus and Frith. However, as already argued, some scholars have integrated in-depth musical analysis and contextual analysis in order to understand the politics of music. ${ }^{18}$ John Street discusses the

15 As already mentioned, Rubén López-Cano's engagement with musical analysis in interpretations of the politics of contemporary Cuban trova and timba also integrate musical analysis in political interpretations of Cuban music. In addition, Moshe Morad's book, Fiesta de diez pesos: Music and Gay Identity in Special Period Cuba (London: Ashgate, 2015); and Kjetil Klette Bøhler, 'Grooves, Pleasures and Politics in Salsa Cubana: The Musicality of Cuban Politics and the Politics of Salsa Cubana' (DPhil diss, University of Oslo, 2013), can also be situated within this tradition. Moore, Music and Revolution; Perna, Timba.

16 Negus, Popular Music in Theory, 192.

17 Frith, Performing Rites, 26.

18 In addition to the work already mentioned by Barry Shank and Noriko Manabe, see, for example, Richard Middleton, Musical Belongings: Selected Essays (London: Ashgate, 2009); David Brackett, "The Politics and Practice of "Crossover" in American Popular Music, 1963 to 1965', Musical Quarterly 78/4 (1994); and the following by Robert Walser, 'Rhythm, Rhyme, and Rhetoric in the Music of Public Enemy', Ethnomusicology 39/2 (1995), 'The Body in the Music: Epistemology and Musical Semiotics' College Music Symposium 31 (1991), 'Popular Music Analysis: Ten Apothegms and Four Instances', in Analyzing Popular Music, ed. Allan Moore (Cambridge: Cambridge University 
theoretical implications of the presented arguments by distinguishing between a 'political theory of music' and a 'musical theory of politics' - where the former relies upon contextual analysis and the latter approaches the politics of music from within the musical text itself:

Glibly, we might say that . . . [existing studies] have provided a political theory of music, but what is also needed is a musical theory of politics . . . It is the political possibilities inherent in pleasure that are important. Musical - or any other cultural - texts cannot be read simply as documents of political aspiration or resentment or compliance. ${ }^{19}$

Street finds that our understanding of the politics of music must also take into account how music becomes political in the aesthetic experience of it, by moving people and bringing them together to speak in new voices. ${ }^{20}$ While Street does not carry out musical analysis himself, he redefines the relationship between the musical and the political conceptually in ways that allow in-depth descriptions of musical structures to matter as descriptions of political experience. He does so by elaborating on the intersection between aesthetics and politics in musical experience, when he argues: 'Understanding music's place in political participation means, at the very least, asking how it seeks to move those who hear and perform it. ${ }^{, 21}$ He points to Bob Dylan as an artist who instigates political values and relationships through the aesthetic qualities of his music. $^{22}$

In an influential article written more than two decades ago Robert Walser had already warned us against reducing music to a form of literal communication in a manner which fails to account for the aesthetic pleasures through which it communicates (such as the design of its grooves or the shape of its melodies). ${ }^{23}$ Anticipating Street's arguments in an analysis of Public Enemy, Walser writes: 'Only the musical aspects of rap can invest [rapper Chuck D's] words with their affective force. ${ }^{24}$ More importantly, Walser specifies how this affective force operates musically and politically in particular sonic relationships by combining music transcription and analysis with a broader contextual analysis of Public Enemy's rapped lyrics. Despite a growing number of studies in this area, ${ }^{25}$ however, a musical theory of politics remains elusive. ${ }^{26}$ This is partly because the very idea of 'politics' and 'the social' seems poorly

Press, 2003), and Running with the Devil: Power, Gender, and Madness in Heavy Metal Music (Middletown, CT: Wesleyan University Press, 1993).

19 John Street, "Fight the Power": The Politics of Music and the Music of Politics', Government and Opposition 38/1 (2003), 126.

20 Street, Music and Politics, 43.

21 Street, Music and Politics, 48.

22 Street, "Fight the Power", 128.

23 Walser, 'Rhythm, Rhyme, and Rhetoric in the Music of Public Enemy', 194.

24 Walser, 'Rhythm, Rhyme, and Rhetoric in the Music of Public Enemy', 193-4.

25 See, for example, Shank, The Political Force of Musical Beauty; Noriko Manabe, The Revolution Will Not Be Televised; Jocelyne Guilbault, 'Party Music, Affect and the Politics of Modernity', Journal of World Popular Music 6/2 (2019); Thomas Turino, Music as Social Life: The Politics of Participation (Chicago: University of Chicago Press, 2008); Manabe, 'Women's March Colloquy-Chants of the Resistance'.

26 Street, "Fight the Power", 126. 
fit to studies of musical details (e.g., interpretations of music transcriptions) due to differences in their levels of abstraction. In short, 'politics' and 'the social' are big words loaded with theoretical baggage of different kinds while the musical, understood as transcribed musical structures, refers to sonic utterances with aesthetic meanings that are limited in time and space. ${ }^{27}$ To overcome this conceptual problem I propose a theoretical redefinition of the relationship between the musical and the political inspired by Bruno Latour's work on relational agency and his understanding of aesthetic experiences as transformative coupled with Jacques Rancière's rethinking of the politics of aesthetics. Importantly, this redefinition accepts parts of Negus and Frith's argument that an understanding of the politics of music requires an engagement with 'the social'. However, this presupposes a specification of what is meant by 'the social'.

\section{Latour's critique of the social}

In Reassembling the Social, Latour uses Actor-Network Theory (ANT) to criticize the tendency towards what he interprets to be a tautological understanding of 'the social' within the social sciences. According to Latour, the social must be redefined, because it is no longer clear what the term refers to; the social could explain the social'. ${ }^{28}$ The problem he sees is that this aspect of social theory has become a self-fulfilling prophecy: 'Sociologists of the social always have at their disposal a stable and absolute third term in which to translate all the vocabularies of the informants, a master vocabulary which acts as a sort of clearing house for instantaneous exchanges between goods that all share the same basic homogeneous quality - namely, to be social. ${ }^{29}$ Latour's response to this problem is to re-examine the empirical level of the social sciences: 'It is never clear in which precise sense social sciences can be said to be empirical', he observes before advocating for more exact concepts and more precise observation methods, so that researchers must 'slow down at each step' of their analyses. ${ }^{30}$ Latour's ANT, then, presents a more cautious and decidedly less glamorous pace of scholarly progress: 'Sociologists of the social seem to glide like angels, transporting power and connections almost immaterially, while ANT scholars have to trudge like an ant, carrying the heavy gear in order to generate even the tiniest connection . . Social scientists will fall asleep long before actors stop deluging them with data. ${ }^{31}$ Latour does not abandon the notion of

27 Importantly, this understanding of musical structures has nothing to do with transcendental aesthetics, understanding of musical works as 'autonomous' or ideas of 'the musical genius'. Instead, it is part of an empirical approach to music transcription and analysis inspired by John Blacking's argument that 'Even if a person describes musical experiences in the technical language of music [music notation], he is in fact describing emotional experiences which he has learned to associate with particular patterns of sound.' John Blacking, How Musical is Man? (Seattle: University of Washington Press, 2000), 52. Understood in this sense music transcription and analysis are techniques of empirical research that allows us to 'zoom in' on particular aspects of musical experience that are difficult to convey and describe with words alone.

28 Latour, Reassembling the Social, 3.

29 Latour, Reassembling the Social, 36.

30 Latour, Reassembling the Social, 22-7.

31 Latour, Reassembling the Social, 25-47. 
the social as such but seeks to redefine it via his demand for detailed, descriptive studies of how it plays out in the relationships between specific objects and people.

\section{Actants, relational agency, and aesthetics}

Latour's critique of the social is simultaneously a redefinition of agency. ${ }^{32}$ Instead of viewing agency as a fixed human property, ${ }^{33}$ he frames it as relational and draws attention to the multiple feedback loops between humans and material objects in practice. For example, the musical performance of a salsa orchestra both shapes and is shaped by a dancing crowd, thanks to the interaction of social dynamics and musical structures in cultural practice. In this sense, agency is about the ability to act and, by extension, make a difference independent of whether it is caused by human motivation or a material phenomenon. Latour captures this quality through the notion of the actant and places his definition of agency within the semiotic tradition: 'An "actor" in [ANT] is a semiotic definition - an actant - that is, something that acts or to which activity is granted by others. It implies no special motivation of human individual actors, or of humans in general. An actant can literally be anything provided it is granted to be the source of an action. ${ }^{34}$ Rather than representing a passive backdrop for human action, objects as actants 'authorize, allow, afford, encourage, permit, suggest, influence' human action and perception in conjunction with human motivation. ${ }^{35}$

In the book An Inquiry into Modes of Existence, Latour elaborates on how actants operate in aesthetic experiences. ${ }^{36}$ He finds that the arts create new social realities through their own means because they 'offer us an imagination that we would not have had without them'. ${ }^{37}$ This argument evokes Robert Putnam's observation at the end of Bowling Alone that, while singing together does not require shared identities and ideologies, it is still 'capable of constituting a sense of community that would otherwise not exist'. ${ }^{38}$ Following Latour part of this can only be understood by recognizing the music itself as such and he gives the following example: 'The Magic Flute, while there are hundreds of ways to perform it, the opera itself is what authorizes and incites us to perform it in all those ways and more. ${ }^{39}$ To understand how the Magic Flute impacts such subjectivities and communities, we must first listen to it and try to describe how it moves us. Put more generally, studies of the arts should be grounded

32 Georgina Born, 'On Musical Mediation: Ontology, Technology and Creativity', Twentieth-Century Music 2/1 (2005); Benjamin Piekut, 'Actor-Networks in Music History: Clarifications and Critiques', Twentieth-Century Music 11/2 (2014).

33 See, for example, Anthony Giddens. The Constitution of Society: Outline of the Theory of Structuration (Berkeley: University of California Press, 1984), 9.

34 Latour, 'On Actor-Network Theory', 365.

35 Latour, 'Reassembling the Social', 72.

36 Latour, An Inquiry into Modes of Existence, 233-59.

37 Latour, An Inquiry into Modes of Existence, 240.

38 Robert D. Putnam, Bowling Alone: The Collapse and Revival of American Community (New York: Simon \& Schuster, 2000), 411.

39 Latour, An Inquiry into Modes of Existence, 240. 
in the transformative potential of the aesthetic experience, which can change our sense of being socially, politically, and culturally through sensory engagement:

A work of art engages us, and if it is quite true that it has to be interpreted, at no point do we have the feeling that we are free to do 'whatever we want' with it. If the work needs a subjective interpretation, it is in a very special sense of the adjective: we are subject to it, or rather we win our SUBJECTIVITY through it. Someone who says 'I love Bach' becomes in part a subject capable of loving that music; he receives from Bach, we might almost say that he 'downloads' from Bach, the wherewithal to appreciate him. Emitted by the work, such downloads allow the recipient to be moved while gradually becoming a 'friend of interpretable objects'. If listeners are gripped by a piece, it is not at all because they are projecting their own pathetic subjectivity on it; it is because the work demands that they, insignificant amateurs, brilliant interpreters, or passionate critics, become part of its journey of instauration - but without dictating what they must do to show themselves worthy of it. ${ }^{40}$

Understood in this sense, music and aesthetic experiences carve out specific forms of being-in-the-world through their own 'actantial' logic, and sonic objects and listening subjects mutually shape one another in social practice. ${ }^{41}$ To grasp such processes, we must do more than describe the social dynamics of a dancing crowd during a salsa concert through ethnographic field notes. We must also transcribe the sonic events which enable dance moves and pleasurable sensations to be felt and performed in the first place by integrating ethnographic and musical analysis into our approach. In this way, we will generate a fuller accounting of how specific organizations of sounds in time invite participating listeners into states of 'being-in-the-groove'. ${ }^{42}$ Such processes are simultaneously social and musical, as underscored by Charles Keil and Steven Feld as grooves create new ways of being together and apart. ${ }^{43}$

Latour's presented arguments invite us to rethink the relationship between ethnographic and music transcription as descriptions of integrated musical actants by interpreting structures of musical sounds (e.g., a groove) and structures of social organization (e.g., a dancing community) as mutually shaped by each other in time. Such interactions afford rather than determine particular relationships between sonic objects and participating subjects and echo recent studies on musical affordances within music psychology and musicology. ${ }^{44}$

40 Latour, An Inquiry into Modes of Existence, 241

41 Latour, An Inquiry into Modes of Existence, 247.

42 Anne Danielsen, Presence and Pleasure: The Funk Grooves of James Brown and Parliament (Middletown, CT: Wesleyan University Press, 2006), 11.

43 Charles Keil and Steven Feld, Music Grooves (Chicago: Chicago University Press), 22-4.

44 See, for example, Eric F. Clarke, Ways of Listening: An Ecological Approach to the Perception of Musical Meaning (Oxford: Oxford University Press, 2005), and 'The Impact of Recording on Listening', Twentieth-Century Music 4/ 1 (2007), 48; Patrik Juslin and John Sloboda, Handbook of Music and Emotion: Theory, Research, Applications (New York: Oxford University Press, 2011); Braxton Shelley, 'Analyzing Gospel', Journal of American Musicological Society 72/1 (2019); Mark Slater, 'Timbre and Non-Radical Didacticism in the Streets' A Grand Don't Come for Free: A Poetic-Ecological Model', Music Analysis, 30/2-3, (2011); Michael Spitzer, 'Mapping the Human Heart: A 
Understanding musical actants at this level invite in-depth analysis of interactions between sonic and social events that shed new light on how music creates subjectivities and builds communities sonically and socially. ${ }^{45}$ While Latour's arguments invite us to pay more attention to interactions between sounds and people, we have not yet elaborated on the politics of such interactions. The specifically political ramifications of this robust engagement will become clearer through a reappraisal of the perspectives in Rancière's Politics of Aesthetics.

\section{Rancière's Politics of Aesthetics}

Rancière paraphrases some of Latour's arguments when opposing Marxist approaches to a politics of aesthetics modelled on a priori distinctions between base and superstructure. ${ }^{46}$ He redefines the relationship between aesthetics and politics as contingent and argues that aesthetic sensations have the ability to create new forms of equality by shaping subjectivities and building communities outside what is traditionally considered the political order (e.g., government, parties, and institutions). ${ }^{47}$ Echoing Aristotle's notion of a political citizen as one 'who partakes in the act of ruling and the act of being ruled', ${ }^{48}$ Rancière locates the political in people's sharing of a common world in which values and opinions can be articulated. ${ }^{49}$ Rancière conceives aesthetic experiences as a priori to politics, as they define the preconditions for how the common is constituted within the community, when he argues:

Holistic Analysis of Fear in Schubert', Music Analysis 29/1-3 (2010). The present approach to musical actants may perhaps be illuminated by Latour and other ANT scholars' work on the importance of developing different 'scripts' through particular methods inspired by theories on relational agency. See, for example, Björn Sonnenberg-Schrank, Actor-Network Theory at the Movies: Reassembling the Contemporary American Teen Film with Latour (Cham: Palgrave Macmillan, 2020), 1-29; Arthur Tatnall and Bill Davey, 'The Internet of Things and Beyond: Rise of the Non-Human Actors', International Journal of Actor-Network Theory and Technological Innovation 7/4 (2015); and Madeleine Akrich, 'The De-scription of Technical Objects', in Shaping Technology/Building Society: Studies in Sociotechnical Change, ed. Wiebe E. Bijker and John Law (Cambridge, MA: MIT Press, 1992). Such a (de)-script-(ive) interpretation draws attention to musical analysis as a descriptive method and reminds us that even though transcription-based musical analysis conceals, it also reveals features of the music experience that are difficult to capture with words alone. In short, it translates musical sounds in time to a system of representation that makes visible the temporal relationship between musical events and thus, potentially, provides new insights into how melodies and grooves work, among other things. However, while this discussion is important, it is beyond the scope of the present article to dig further into this debate and more work is needed on the relationship between 'scripts' in Actor-Network Theory and music transcription and analysis in the musical sciences.

45 For a similar reading of Latour's argument, see Julian Henriques, 'The Vibrations of Affect and Their Propagation on a Night Out on Kingston's Dancehall Scene', Body and Society 16/1 (2010). For related, but different interpretations of Latour's arguments see Born, 'On Musical Mediation', and Piekut, 'Actor-Networks in Music History'. Lastly, see recent studies in ethnomusicology on the relationship between musical instruments and social organization, including P. Allen Roda, 'Ecology of the Global Tabla Industry', Ethnomusicology 59/2 (2015); and Eliot Bates, 'The Social Life of Musical Instruments', Ethnomusicology 56/3 (2012).

46 Rancière, The Politics of Aesthetics, 49-50.

47 Rancière, The Politics of Aesthetics, 51.

48 Aristotle quoted in Thomas Pangle, Aristotle's Teaching in the 'Politics' (Chicago: University of Chicago Press, 2013), 63.

49 Andrew Schaap, 'Enacting the Right to Have Rights: Rancière's Critique of Hannah Arendt', European Journal of Political Theory 10 (2011). 
What is common is 'sensation'. Human beings are tied together by a certain sensory fabric, I would say a certain distribution of the sensible, which defines their way of being together, and politics is about the transformation of the sensory fabric of the 'being together' ... Aesthetic experience ... is a common experience that changes the cartography of the perceptible, the thinkable and the feasible. As such, it allows for new modes of political construction of common objects and new possibilities of collective enunciation . . . Film, video art, photography, installation, [music], etc. rework the frame of our perceptions and the dynamism of our affects. As such they may open new passages toward new forms of political subjectivization. ${ }^{50}$

By defining politics in aesthetic terms - as the production of commonalities through shared values, feelings, opinions, and preferences - Rancière enables the political to emerge in aesthetic experience as such.

Rancière further introduces a distinction between 'politics' and 'the police' to unpack the ways in which aesthetics can reconfigure political subjectivities and communities. The police label the regulation of the space of opinions, values, and preferences by larger institutions, while politics labels people's potential to challenge such social orders through aesthetic expression:

The police, to begin with, is defined as an organisational system of coordinates that establishes a distribution of the sensible or a law that divides the community into groups, social positions and functions. This law implicitly separates those who take part from those who are excluded, and it therefore presupposes a prior aesthetic division between the visible and the invisible, the audible and the inaudible, the sayable and the unsayable. The essence of politics consists of interrupting the distribution of the sensible by supplementing it with those who have no part in the perceptual coordinates of the community, thereby modifying the very aestheticopolitical field of possibility ... Those who have no name, who remain invisible and inaudible, can only penetrate the police order via a mode of subjectivization that transforms the aesthetic coordinates of the community by implementing the universal presupposition of politics: we are all equal. ${ }^{51}$

The ways in which aesthetic perceptions unfold - in the present study, through moving to rhythms or singing together - can change a community by generating values, preferences, and opinions which challenge the police (in Rancière's use of the word). Rancière describes such interventions as 'dissensus', 52 and he is correspondingly critical of any notion of politics

50 Jacques Rancière, 'Aesthetic Separation, Aesthetic Community: Scenes from the Aesthetic Regime of Art', Art and Research 2, (2008), 4-14.

51 Rancière, The Politics of Aesthetics, xiii.

52 Rancière, The Politics of Aesthetics, 52-65. For an elaboration of his notion of dissensus, see Jacques Rancière, Dissensus: On Politics and Aesthetics (London: Bloomsbury, 2015). Here, I am deliberately repositioning Rancière's arguments as a toolkit with which to rethink the political force of musical grooves in Cuba. I was encouraged to do so after a discussion with Rancière in his apartment in Paris in 2019, where we discussed how such an effort might succeed. 
modelled primarily on consensus, such as established forms of participatory democracy and traditional forms of deliberation. He views politics as intrinsically linked to rupture and disagreement and argues that such interventions are most profoundly articulated through aesthetic means which 'redistribute the sensible', ${ }^{53}$ simultaneously changing the relationship between the audible and the arguable.

\section{Towards a musical theory of politics}

Applied to musicological research, Rancière's and Latour's perspectives encourage us to consider more carefully the role of pleasure and participation in musical articulations of politics. ${ }^{54}$ Such an approach would draw attention to important musical complexities which are commonly excluded from studies on the politics of music, including grooves and melodies. It is perhaps better understood as a micro-politics of affective engagement that draws attention to how perceptions of musical sounds create novel ways of being together and apart where particular values, visions, and sentiments are constructed. ${ }^{55}$ To the Cuban anthropologist Fernando Ortiz, this is not a new condition of either music or politics. He argues that Afro-Cuban music has for centuries mobilized its sonic pleasures to create new ways of being together on the island: 'Afro-Cuban music is fire, tastiness and smoke, syrup, sensual flavour [sandunga], comforts/relief [alivio]; it is like a sonic rum that you drink through your ears, that brings the people together, making them equal and bringing forth life through the senses. ${ }^{56}$ As I will discuss, such music-enabled subjectivities and communities may also redistribute the sensible in contemporary Cuba by changing 'who can have a share in what is common to the [Cuban] community, ${ }^{57}$ ultimately challenging the 'political order' long defined by the revolution. To understand how musical actants trigger such processes, we must complement conceptual interdisciplinarity with different methods and data sources, to which I will turn next.

\section{Methodologies and data sources}

The following discussion draws upon ethnographic data (interviews, fieldnotes, and pictures) and the musical analysis of grooves, melodies, and lyrics of Havana D'Primera's song 'Pasaporte', which first became popular on the Cuban live scene in autumn 2010, two years before its official release on the CD Pasaporte (2012). Since then it has been one of

53 Rancière, The Politics of Aesthetics, 13.

54 Part of this has already been elaborated in Shank's The Political Force of Musical Beauty.

55 Such understandings of politics resonate with some recent music scholarship, including Shank, The Political Force of Musical Beauty, and Guilbault, 'Party Music, Affect and the Politics of Modernity', and more broadly with new research which links theories on affect with politics, including Brian Massumi, Politics of Affect (Cambridge: Polity Press, 2015); Emma Hutchison, Affective Communities in World Politics (Cambridge: Cambridge University Press, 2016); and Brigitte Bargetz, 'The Distribution of Emotions: Affective Politics of Emancipation', Hypatia 30/ 3 (2015).

56 Fernando Ortiz, La africanía de la música folklórica cubana (Havana: Editorial Letras Cubanas, 2001), 13. Translation by the author.

57 Rancière, The Politics of Aesthetics, 8. 
the most popular songs on the island. I focus specifically on how the song was performed at a 'matinée concert' (6 to 9 pm) at Casa de la Música, Miramar, Havana, on 7 December 2010. These concerts are discounted for Cuban citizens and are among the most important live venues for timba in Havana. I accompany my examination of the live event with insight from my analysis of the recorded version, where specific aspects of the music are most readily available for in-depth transcription and musical analysis. ${ }^{58}$ I view my two modes of analysis, ethnographic and musical, as complementary means of demonstrating how the aesthetic qualities of the song open a space for political communication. The modes tend to overlap as well - for example, my ethnographic fieldnotes featured descriptions of social interactions as well as music transcriptions and analysis, conducted on the fly or when revisiting the event via my memory of it. ${ }^{59}$

\section{Selecting, collecting, and representing ethnographic data}

During the concert, the venue was packed and the audience was predominantly Cuban. I had a notebook and a camera but sought first and foremost to study the music through cultural participation, which meant that I spent most of the time dancing as my means of observing and studying the musical sounds as shared physical experience. ${ }^{60} \mathrm{I}$ then transitioned from 'embodied participation', or being aesthetically engaged through dancing and listening, to 'reflective observation', or recording fieldnotes and reflections afterward as I sought to reconstruct the concert experience. While writing, I paid particular attention to how the music sounded; what emotions, practices, and values it suggested; and how the audience responded to it. I also noted down key features of the music's rhythmic and melodic organization. To

58 It is important to distinguish the musical structures in my transcriptions of the recording from the musical structures in a typical score. While the latter privileges the perspective of the composer, the former privileges the perspective of the listener, and therefore, in my view, those specific sonic relationships which enable songs to acquire and activate their aesthetic meaning.

59 Ethnographically informed musical analysis mainly identifies melodies and coros (refrains), key features of the bass tumbao, and certain rhythmic structures and interactions which I was able to confidently recall. Other parts of the music experience, such as the intricate polyrhythmic design of the montuno, seemed crucial in generating aesthetic pleasure according to my initial fieldnotes but where difficult to transcribe in real time. Still, in-depth listening to the recorded version of the song allowed me to transcribe and discuss these musical events and to integrate insights from the ethnographic and music transcriptions in order to provide a fuller account of how grooves mattered aesthetically and politically as particular organizations of musical sounds. To make this data-triangulation transparent, and to link the ethnographic and musical analysis together, I have added time stamps throughout the music analysis that corresponds with the recorded version.

60 For more on this form of ethnography, see, for example, Kay Kaufman Shelemay, 'The Ethnomusicologist, Ethnographic Method, and the Transmission of Tradition', in Shadows in the Field: New Perspectives for Fieldwork in Ethnomusicology, ed. Gregory F. Barz and Timothy J. Cooley (Oxford: Oxford University Press, 1997); Katherine J. Hagedorn, Divine Utterances: The Performance of Afro-Cuban Santería (Washington, DC: Smithsonian Institution Press, 2001); Timothy Dale Fuson, 'Musicking Moves and Ritual Grooves across the Moroccan Gnawa Night' (DPhil diss., University of California, Berkeley, 2009); Garcia, 'Feeling the Vibe'; Sydney Hutchinson, From Quebradita to Duranguense: Dance in Mexican American Youth Culture (Tucson: University of Arizona Press, 2007), and, ed., Salsa World: A Global Dance in Local Contexts (Philadelphia: Temple University Press, 2015). 
condense my data, I arranged my 'summary fieldnotes' according to my specific points of interest.

I also conducted complementary semi-structured interviews with 'María' (real name withheld), a timba fan with no musical training, and with three established timba musicians: Alexander Abreu, the composer of 'Pasaporte'; César 'Pupy' Pedroso, a legendary Cuban pianist in the timba tradition; and Alexis Rodriguez, a younger Cuban percussionist with experience in many timba orchestras. The interviews followed a similar guide, lasted around an hour, and were recorded on a tape recorder on the spot and transcribed afterwards. The present study draws on selected parts of the interviews to complement its musical and ethnographic interpretations of the song with emic perspectives on the social and aesthetic meanings of timba. All the interviewees signed an informed consent. While María (born 1960) is a pseudonym to protect the participant's anonymity, ${ }^{61}$ Alexander Abreu (born 1976), César 'Pupy' Pedroso (born 1946), and Alexis Rodriguez (born 1983) all agreed to participate under their real names. ${ }^{62}$

\section{Music analysis as a method: the interplay between grooves, melodies, and lyrics}

Methodologically, my music analyses involved close and repeated listening at the live performance, as best I could, as well as to the recording. I focused particularly on how the music grooved as a verb (the process) by inviting participating listeners to feel particular forms of 'presence and pleasure, 63 and on the groove as a noun (the object) by identifying musical structures of polyrhythmic interaction which made up the larger 'rhythmic fabric' ${ }^{64}$ of interlocking rhythms. In both cases, I interpreted the music in light of my own extensive performance background as a timba pianist since 2006. Thanks to this experience, I was able to transcribe several simplified rhythms and melodies (including the sung melody, the bass tumbaos, and the cascara rhythm) on the spot, and then apply closer analytical scrutiny while listening to the recorded version. Also owing to my experience, I decided to interpret all my transcriptions in the context of the underlying rumba clave, which provided an organizing principle for the groove as a whole. This approach was further informed by a number of scholars working on Cuban rhythms, ${ }^{65}$ and by findings from my interview with Alexander Abreu, who underscored the importance of the clave rhythm in his own music:

61 This procedure follows the research ethics in the field and specifically the Norwegian Centre for Research Data, which has approved the present study. See more about the centre at https://nsd.no/.

62 For a broader elaboration of my use of ethnography as a method while conducting music research in Cuba, and particular challenges related to ethics and being a foreigner ('Yuma'), see Bøhler, 'Grooves, Pleasures and Politics in Salsa Cubana', 69-92.

63 Danielsen, Presence and Pleasure. See also Keil and Feld, Music Grooves, 22-4, and Mark J. Butler, Unlocking the Groove: Rhythm, Meter, and Musical Design in Electronic Dance Music (Bloomington: Indiana University Press, 2006).

64 Danielsen, Presence and Pleasure, 43-73. See also John Miller Chernoff, African Rhythm and African Sensibility (Chicago: University of Chicago Press, 1979); Simha Arom, African Polyphony and Polyrhythm: Musical Structure and Methodology (Cambridge: Cambridge University Press, 2004); J. H. Kwabena Nketia, African Music in Ghana (Evanston, IL: Northwestern University Press, 1963).

65 See, for example, Ives Chor, 'Microtiming and Rhythmic Structure in Clave-Based Music: A Quantitative Study', in Musical Rhythm in the Age of Digital Reproduction, ed. Anne Danielsen (New York: Routledge, 2016); Christopher 
Bøhler: When you sing, do you think about the clave? Do you think consciously about it? Or is it more like you don't care and just sing?

Abreu: Yes, yes, yes, I think about the clave all the time [...] many times the dancer feels the clave. [. . . I am one of those arrangers who always want to play in clave because it is like a pattern that a lot of people understand. I think the clave makes it easier for the dancer to understand what is going on. [...] That is why all the elements in my music have a relationship with the clave - the cascara, campana, the piano, the tumbao [bass], coro, horn section. Everything. ${ }^{66}$

In short, the clave rhythm represented the organizing principle in Havana D'Primera's music which invited people to tap along and engage with their grooves. It also provided a system of rhythmic organization among the musicians which situated Havana D'Primera within a longer history of Cuban popular dance music modelled on similar clave structures. $^{67}$

Inspired by Havana D'Primera's way of notating timba music as well as common approaches to transcribing and composing timba music in Cuba, I decided to represent my transcriptions using a la breve notation. In addition, a la breve notation enhances musical readability and can be found in much existing music scholarship on timba. ${ }^{68}$ As a consequence, I notated the rumba clave's cyclical rhythmic pattern of five strokes over four pulses as two bars of 4/4. According to the distribution of the strokes in these two bars, two possible clave orientations emerge: 3-2 or 2-3 (Example 1).

Washburne, “"Play It Con Filin!”: The Swing and Expression of Salsa', Latin American Music Review 19/2 (1998); Kjetil Klette Bøhler, 'Groove Aesthetics in Afro-Cuban Jazz: Towards an Empirical Aesthetic Theory', Norwegian Journal of Musicology 39/1 (2013); David Peñalosa, and Peter Greenwood, The Clave Matrix: Afro-Cuban Rhythm; Its Principles and African Origins (California: Bembe Books, 2009); and Chris Stover, 'A Theory of Flexible Rhythmic Spaces for Diasporic African Music' (DPhil diss., University of Washington, 2009).

66 Interview with Abreu, Havana, November 2010. Original: Bøhler: ‘ ¿Cuándo cantas piensas mucho en la clave? Piensas conscientemente en la clave? ¿O no te importa?' Abreu: 'Sí, sí, sí, pienso en la clave todo el tiempo ... muchas veces el bailarín siente la clave... Soy uno de esos arreglistas que siempre quiere llevar la clave porque es como un patrón que mucha gente entiende. Creo que la clave facilita al bailarín entender lo que está pasando... Por eso todos los elementos de mi música tienen una relación con la clave, la cáscara, la campana, el piano, el tumbao [bajo], el coro, la sección de los metales. Todo'.

67 Emilio Grenet was the first to write about the role of the clave across Cuban music styles; see Emilio Grenet, Popular Cuban Music (Havana: Editorial Letras Cubanas, 1939). Since then, many others have extended his arguments. For work by Cuban scholars, see, for example, Leonardo Acosta 'On Generic Complexes and Other Topics in Cuban Popular Music', trans, Daniel Whitesell and Raúl Fernández, Journal of Popular Music Studies, 17/3 (2005); Danilo Orozco, 'El son: ¿ ritmo, baile o reflejo de la personalidad cultural cubana', in Musicología en Latinoamérica, ed. Zoila Gómez García (Havana: Editorial Arte y Literatura, 1984); Argeliers León, Del canto y el tiempo (Havana: Editorial Letras Cubanas, 1984); Fernando Ortiz, La clave (Havana: Editorial Letras Cubanas, 1995); Olavo Alén, Géneros de la música cubana (Havana: Editorial Pueblo y Educación, 1977), and De lo afrocubano a la salsa (Havana: Ediciones Artes, 1994). For other work on clave, see Chris Washburne, 'The Clave of Jazz: A Caribbean Contribution to the Rhythmic Foundation of an African-American Music', Black Music Research Journal, 17 (1997); Peñalosa and Greenwood, The Clave Matrix; and Kjetil Klette Bøhler, 'Groove Aesthetics in Afro-Cuban Jazz'.

68 It means that a notated crotchet feels like an quaver in practice, but its notation as a crotchet in $a$ la breve is easier to read and interpret. A number of scholars on Cuban music transcribe the music along these lines. 


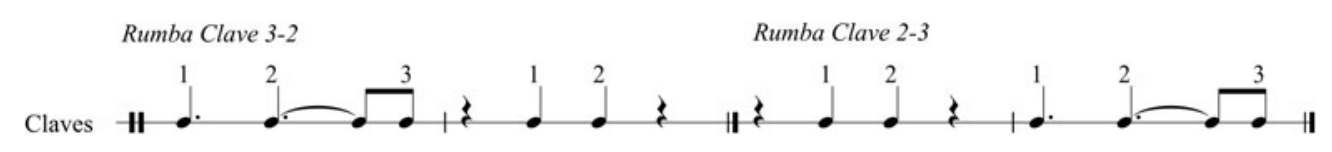

Example 1 Rumba clave in 3-2 and 2-3 with each accent numbered.

Salsa musicians and scholars label the two bars that make up the clave rhythm either the 'three-side' or the 'two-side', depending on where the clave starts. ${ }^{69}$

Research by Ives Chor suggests that many clave-organized grooves tend to be structured in a binary system of syncopated rhythmic tension and release over the two-bar pattern. ${ }^{70}$ The three-side tends to be more syncopated than the two-side. A rhythmic pattern can also be 'in clave' when it aligns with some of the strokes of the clave. Alejandro L. Madrid and Robin Moore describe the effect upon the alternate pattern as 'claved', and I use this term throughout the analysis. ${ }^{71}$ In addition to the clave, I will pay particular attention to the interaction between different rhythmic riffs or cells, including the interplay between the cascara and different campana patterns, as well as the interactions between bass and piano tumbaos, which are key elements of the timba aesthetic. ${ }^{72}$

\section{Analysing melodies and lyrics in the context of the groove}

To diagram the musical context of the lyrics of 'Pasaporte', I have divided them up according to melodic phrases - the ways in which a larger textual narrative tends to be performed via sung motifs (with pauses before and after). ${ }^{73}$ When analysing the structure of a given motif, I will identify melodic, harmonic, and rhythmic features of interest, including stepwise movements, large intervals, and triadic leaps, as well as the overall rhythmic design and harmonic context of the motifs sung melody. I further situate the melodic phrases and motifs within the experience of the music by engaging the overall musical narrative and especially its interlocking rhythms.

I then unpack the lyrics in the context of the melodic phrases and motifs through which they are experienced. Each motif s lyrics are 'statements' which I am careful to synthesize over the course of the entire song, drawing upon both existing research and my fieldwork in Cuba to understand how these statements invoke a shared cultural reality which makes them politically meaningful. To fully capture how the live aesthetic experience of

69 See, for example, Perna, Timba; David García, Arsenio Rodríguez and the Transnational Flows of Latin Popular Music (Philadelphia: Temple University Press, 2006); Moore, Music and Revolution; and Bøhler 'Groove Aesthetics in Afro-Cuban Jazz'.

70 Chor, 'Microtiming and Rhythmic Structure in Clave-Based Music', 32-4. This view is supported by, among others, Washburne, “"Play It Con Filin!”, and Bøhler, 'Grooves, Pleasures and Politics in Timba'.

71 Madrid and Moore, Danzón.

72 This approach is in line with existing scholarship. See Sarah Town, “Timbeando en Nueva York”: Cuban Timba Takes Root Abroad', Ethnomusicology 63/1 (2019); Orlando Enrique Fiol, 'Grooves and Waves: Cyclicity and Narrativity in Cuban Timba Piano', Latin American Music Review 33/1 (2012), and 'Cubaneo in Latin Piano: A Parametric Approach to Gesture, Texture, and Motivic Variation' (DPhil diss., University of Pennsylvania, 2018).

73 This definition of a musical phrase is inspired by Jean-Jacques Nattiez, Music and Discourse: Toward a Semiology of Music (Princeton: Princeton University Press, 1990) and David White, The Analysis of Music (Metuchen: Scarecrow Press, 1984), 36. 
'Pasaporte' expresses political values in Havana, I will follow the musical order of the song (intro, verse, montuno) as a narrative structure for the analyses while moving between event descriptions based upon ethnographic data (interviews and field notes accounts), close music analysis, and contextually informed analysis of the lyrics.

\section{Musical constructions of a 'Pasaporte' community live at Casa de la Música}

Yandy González, the bass player in Habana D'Primera, starts the 'Pasaporte' groove with a smooth, laid-back bass tumbao which articulates beats 2 -and, 3, and 4 via an upward movement from the fifth to the seventh and then the root in B minor. After one repetition, he repeats the figure but in $\mathrm{F} \sharp$ minor, revealing that the latter is the tonic and the former the subdominant of what we are about to hear. The fourth beat is the most accentuated and is allowed to sound out more than the others. At Casa de la Música, these syncopated opening sounds, which are at once new and familiar to fans of the genre, encouraged people to groove to the music by dancing or moving along with it. As such, the bass line functioned as the song's first musical actant by compelling the audience to participate in the sonic event with their own bodies.

Of course, this work is not done by the bass alone but by all the instruments, amplifying and nuancing the engagement with the event participants. A profound rhythmic dialogue emerges between the bass and the syncopated pattern on the cascara, the pulse-oriented marching of the güiro, maracas, and congas, and, of course, the rumba clave. Atop this polyrhythmic fabric, pianist Tony Rodriguez plays thick, jazzy chords with ninths and elevenths while Guilhermo del Toro interjects into the rhythmic dialogue with short improvisations on the bongo. This musical organization shaped, and was shaped by, changes in the social fabric as dance moves among a participating audience allowed the aforementioned sounds to be repeated and vice versa. In short, agency was distributed and both in the hands of dancing participants and in the sounds of grooving instruments.

After a couple of minutes, band leader Alexander Abreu joins this joyful atmosphere, and the people in the audience scream and put their hands in the air. Abreu uses the musical space provided by the grooving instruments to interact with the event participants and talk about his band. Someone in the audience gives Abreu something which looks like a notebook, and Abreu holds it up, chanting, 'Look at this, look at this, look at this, look at this' ('Mira, mira, mira, mira'). He then shows everyone the passport, itself a political gesture evoking the experience of the many Cubans who have left the country in pursue of a better future. Then Abreu starts singing Barry Manilow's big hit from 1978, 'Copacabana', as an introduction to his own song, atop the same bass vamp. It works both musically and socially, as most of the audience members know the song and sing along. Through this gesture, Abreu joins the performance tradition of timba star Manolin el Medico de la Salsa, who often quoted Manilow's 'Copacabana' during his performances in the 1990s. Both the groove and the Manilow refrain repeat as the audience immerses itself into the groove as social organization and musical structures act upon each other in time. Repetition is not boring but joyful. Part of the sonic and social interactions that allowed that community and feeling to be produced can be illustrated through the transcription in Example 2. 

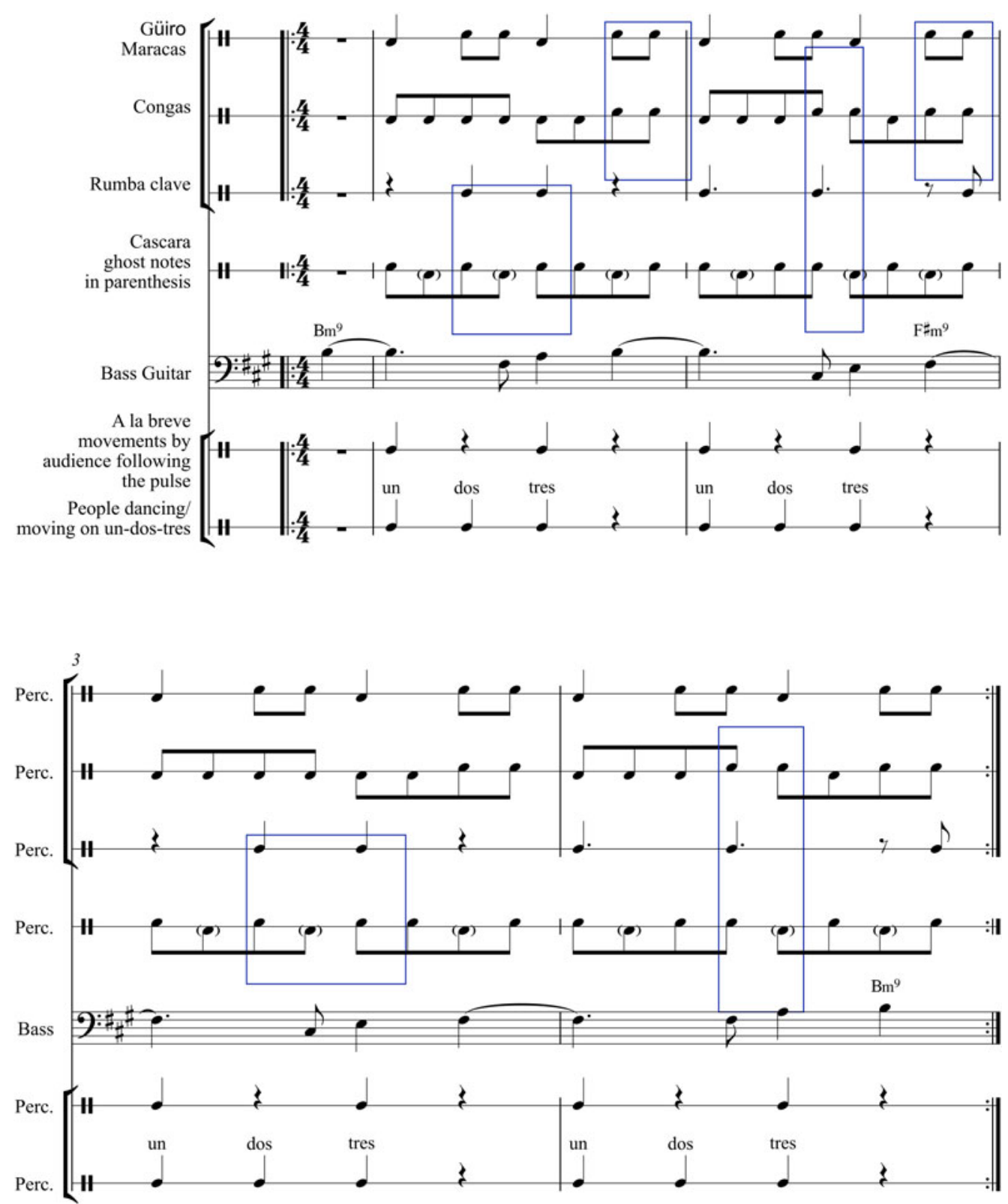

Example 2 Transcription of the two-bar polyrhythmic texture played by the güiro, maracas, congas, rumba clave, cascara, and bass. The audience movements are summarized in lines 6 (basic rhythmic engagement following the pulse) and 7 (full rhythmic engagement following 'un-dos-tres' movements).

The final two staff lines in the figure capture key movements among the audience members who responded to the song's groove, either by responding to the pulse (line 6) or by dancing in couples and articulating movements of 'un-dos-tres' following timba conventions (line 7).

Through such forms of embodied engagement these rhythmic interactions (lines 1-5) worked as musical actants by creating an affective community of being together. More 
specifically, the subdivisions and syncopations in cascara and congas expressed musical articulations of stability (subdivisions) and friction (syncopated accents) at the same time that invited us all into introductory states of 'being-in-the-groove'. ${ }^{74}$ The two rhythms were also performed 'in clave' as they interacted with keystrokes in the clave rhythm such as the 2 -and on the three-side and the two on-beats on the two-side (see squares across staff lines). That joyful rhythmic atmosphere was further elaborated by the less syncopated stream of subdivisions in güiro, maracas, and congas and particularly thanks to the accentuations of the two last accents in each bar (see squares). In a sense these two articulations constantly induced movements. There was no rest as the rhythms pushed us forward and interlocked with each other. Syncopations were produced by variations and short improvisations that further energized the groove by creating affective ways of being together musically and socially. The extended fourth beat in the bass gained new levels of musical meaning in that polyrhythmic context and invited us all deeper into the groove for each repetition. It was these grooves that allowed the gesture of showing a passport to make sense musically as we had all been together with Havana D'Primera in similar grooves before. We all knew that the song to come was the increasingly popular 'Pasaporte'. Even though it was yet to be released, it was a key ingredient in the musical community Havana D'Primera created between 6 and 9 pm each Tuesday at Casa de la Música, Miramar, in Havana that fall (2010).

\section{Singing together: 'She says life is hard . . . that is why she needs a passport!'}

Abreu invites the rest of his band to join in by saying 'un, dos, ay que rico'. The last three words (in italics) are articulated in a syncopated manner to engage his musical community and introduce a brass figure. The warming up is over, and Abreu next sings the following words as two musical phrases of four motifs each:

(1a) She says life is getting really hard,

$(0: 20-0: 23)$

(1b) with the problems and the censorship,

(1c) that's why

(1d) she needs a passport.

(2a) Essential to walk on other lands,

(2b) at whatever price necessary,

(2c) no fighting,

(2d) no war. ${ }^{75}$

The first statement (1a) evokes the struggle of everyday life in contemporary Cuba in 2010, as Cubans tried to get past what Fidel Castro once termed the 'Special Period' (Período especial), the state of emergency which arose following the nation's break with the socialist bloc

74 Danielsen, Presence and Pleasure.

75 The transcription of sung lyrics is based upon my fieldnotes. It is correlated with the performance of these lyrics in the recording via the times on the left. Original: (1a) Ella dice que la vida se le da bien dura, (1b) con los problemas con la censura, (1c) que por eso, (1d) necesita un pasaporte. (2a) Imprescindible caminar por otras tierras, (2b) al precio que sea necesario, (3) sin lucha, (4) sin guerra. 
led by the Soviet Union in the early 1990s. The conditions drove thousands of Cubans to abandon the country, often risking their lives on the sea in poorly built rafts. ${ }^{76}$ The next statement (1b) evokes the scarcity of basic supplies for the household, among other things, while the third (1c) aims this song's critique directly at the Cuban state by lamenting the degree of censorship on the island - Cubans at the time faced constant political propaganda (e.g., through the official newspapers Granma and Juventud Rebelde), little freedom of expression and highly restricted Internet access. The last statement (1d) offers a solution: 'That's why she needs a passport.' The passport embodies the desire of many Cubans to leave the island for a life elsewhere, preferably reunited with loved ones already living in Europe, the United States, Angola, Latin America, or elsewhere. It also provokes anxiety regarding the requirements for going abroad. The second phrase insists that departure is worth 'whatever price necessary', because it will free the traveller from the 'fighting' and 'war' taking place between the people and their government in Cuba.

In a Rancierian sense, these sung words enact a critique of a Cuban police order defined by revolutionary consensus by making dissensus audible and affective. ${ }^{77}$ The melody, in literal and figurative counterpoint with the rolling groove, prompted the development of new political subjectivities and communities at Casa de la Música that night in 2010. Musical actants accomplished a particular 'redistribution[s] of the sensible ${ }^{78}$ by connecting sounds and bodies through aesthetic pleasure, as we will see from the process of analysing a music transcription in tandem with fieldnotes from the same musical event.

\section{Musical constructions of political critique}

The transcriptions in Example 3 highlight some of the musical structures and interactions which enabled the previously discussed lyrics to matter socially and aesthetically in lived experience.

The first sung phrase (1, bb. 1-2) created affective engagement among participating listeners thanks to an upward diatonic movement starting on the root and ending on the fourth scale degree. Its tonal structure and melodic shape made it easy to sing along. At the end of the phrase some people in the audience joined in with Abreu. As a consequence, Abreu pointed the microphone at the crowd as he sang the final two words, 'bien dura' (b. 2), in a syncopated fashion which enriched the rhythmic fabric. His subsequent singing elaborated on that rhythmic flavour by reshuffling the musical structures entailed in the lyrics (e.g., compare the rhythmic organization of phrase 1, bb. 1-2, and phrase 2, bb. 3-4, both of which are organized around the same melodic material). First, he rhythmically transformed the three syllables which make up 'bien du-ra' into the five syllables of 'con los pro-ble-mas' (b. 3), then the five syllables of 'con la cen-su-ra' (b. 4). The links among these three sung gestures reflected both coherence and development as Abreu rearranged the relationship between two pitches, A and B (see bb. 1-4), rhythmically and melodically to keep the audience engaged in

\footnotetext{
76 See Ted Henken, 'Balseros, Boteros, and El Bombo: Post-1994 Cuban Immigration to the United States and the Persistence of Special Treatment', Latino Studies 3/3 (2005).

77 Rancière, The Politics of Aesthetics, xiii.

78 Rancière, The Politics of Aesthetics, xiii.
} 

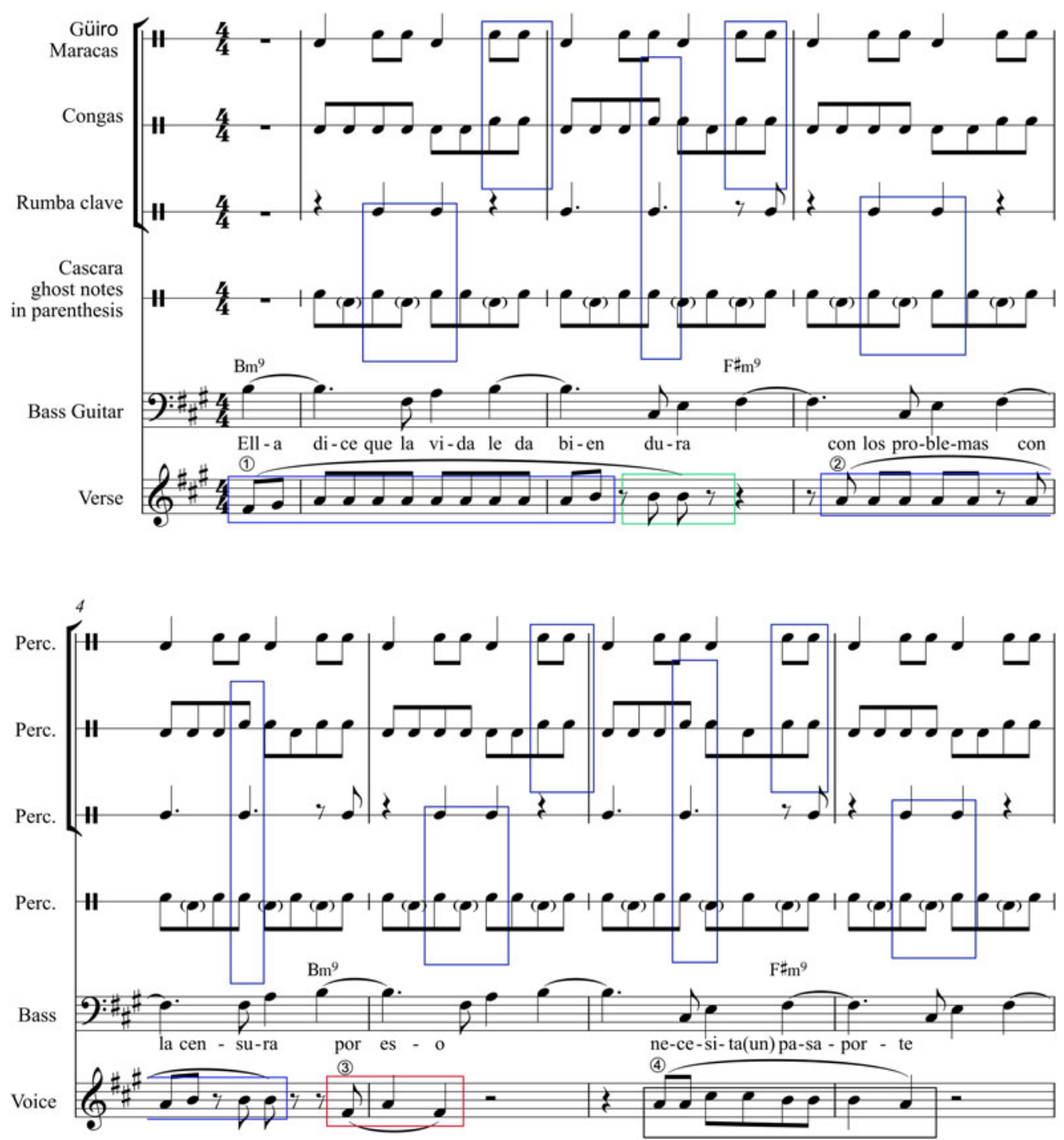

Example 3 Transcription of the first sixteen bars of the sung melody in the context of an accompanying polyrhythmic weave composed by interlocking rhythms on güiro, maracas, congas, rumba clave, cascara, and bass.

the musical narrative. More importantly, these sung words became pleasurable as they interacted with the interlocking patterns of the güiro, maracas, cascara, congas, clave, and bass tumbao (see bb. 1-4). These musical meanings add up to a forceful allusion to the everyday struggles of life in $\mathrm{Cuba}^{79}$ - an allusion understood by almost everybody at Casa de la Música

79 For more, see Mona Rosendahl, Inside the Revolution: Everyday Life in Socialist Cuba (Ithaca, NY: Cornell University Press, 1997); Ariana Hernández-Reguant, Cuba in the Special Period and Ideology in the 1990s (Basingstoke: Palgrave Macmillan, 2009); Sean Brotherton, Revolutionary Medicine: Health and the Body in Post-Soviet Cuba (Durham: Duke University Press, 2012); Ted A. Henken, 'Cuba’s Digital Millennials: Independent Digital Media and Civil Society on the Island of the Disconnected', Social Research: An International Quarterly 84/2 (2017), and 'Balseros, 

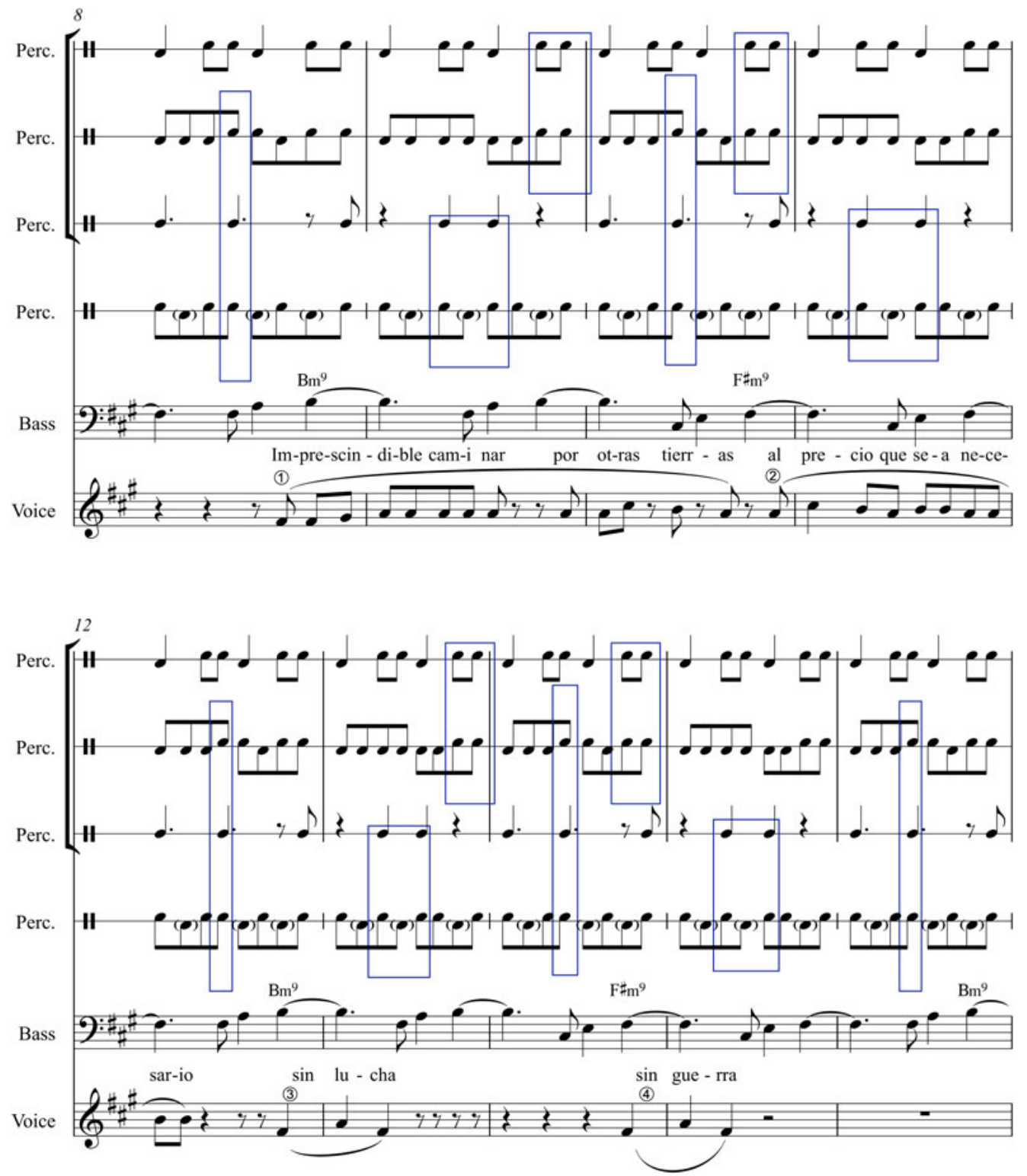

Example 3 Continued.

as they joined together to sing the last line: 'That is why I need a passport!' (see bb. 5-7). The following pause (b. 8) returned the audience's attention to the groove for a moment before Abreu began a second phrase which elaborated on the melodic material presented in the first

Boteros, and El Bombo'; Perna, Timba; Baker, 'Cuba Rebelión', and 'Mala Bizta Sochal Klu: Underground, Alternative and Commercial in Havana Hip Hop', Popular Music 31/1 (2012). 
(compare melodic material in bb. 8-16 with the melodic material sung between bb. 1-8). And again, at the end, the audience joined in when Abreu pointed the microphone at them.

The following part of the verse was also easy to sing along and firmly situated in that $\mathrm{F} \#$ minor mode. As the song developed, the social fabric of the live event intensified - more movement, more singing along, more presence. After a short harmonic detour during the bridge, Abreu returned to the initial bass tumbao that started the song, building anticipation with each repetition as a cowbell appeared to suggest that something is about to happen.

\section{The Montuno}

Then, a momentary break across the instruments, at the end of which began a coro whose rhythmic design suggested that the montuno had started (Example 4).

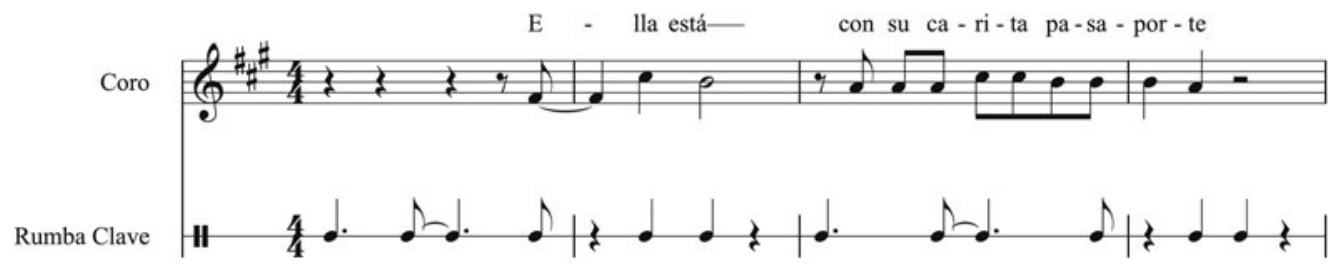

Example 4 Tutti break rendered on the first line with the three-sides of the clave beneath it, followed by the coro (2:15-2:22), which repeated throughout the montuno and was answered by Abreu's guía improvisations.

As Abreu improvised in response to the coro, more people sang along, ${ }^{80}$ and he continued to point the microphone at the crowd, which, thanks to the rhythmic shape of the coro's melody (see Example 4), happily drank that 'sonic rum' about which Fernando Ortiz wrote more than half a century ago. As we all repeated the words 'She is there, with her passport face, surviving the crisis, surviving getting beaten', ${ }^{81}$ what mattered musically was the leap up a fifth from the root on the last clave accent of the three-side (see Example 5, bb. 1-2), followed by the two subsequent vocal articulations on the two-side which retreated downward diatonically from that fifth (see b. 2). That musical gesture animated the words 'she is there' (ella está) - words which aligned the entire crowd with the message and the musicians through syncopated subdivisions (see bb. 3-5 and first part of b.7), rhythmic density, and sharp, percussive consonants.

The transcribed instruments and voices realize two interlocking rhythmic layers. ${ }^{82}$ The first is composed of forward-thrusting, pulse-oriented rhythms and subdivisions of the güiro, maracas, congas, campana, and contra-campana, and especially the alternation between on-beat strikes and quavers in the güiro and maracas, which allowed no rest during the entire

80 Guia improvisations are sung responses to the coro by the lead singer which often elaborate on the coro's melodic and rhythmic content. For descriptions of guía singing, see Fiol, 'Cubaneo in Latin Piano', and 'Grooves and Waves'.

81 Original: 'Ella está con su carita de pasaporte, sobreviviendo a la crisis, sobreviviendo al golpe.'

82 Many scholars have distinguished between different rhythmic layers in various African-derived grooves. See, for example, Arom, African Polyphony and Polyrhythm; Juan Diego Diaz Meneses, 'Listening with the Body: An Aesthetics of Spirit Possession Outside the Terreiro', Ethnomusicology 60/1 (2016); Chernoff, African Rhythm and African Sensibility; Olavo Alén, 'Rhythm as Duration of Sounds in Tumba Francesa', Ethnomusicology 39/1 (1995); Nketia, African Music in Ghana and Bøhler, 'Grooves, Pleasures and Politics in Salsa Cubana'. 



Example 5 Transcription of the coro of 'Pasaporte' in the context of a repeating montuno groove composed of interlocking rhythms played by piano, bass, campana, contra campana, güiro, maracas, and congas. The transcription is based on my fieldnotes and the recording (2:15-2:25).

performance. My percussion teacher, Alexis Rodriguez, described this pattern as the 'horse rhythm' (ritmo de caballo): 'That rhythm is very important for that sabor and energy, to make people move, so that all the other syncopations make sense. It provides a reference, 
in a sense. ${ }^{83}$ Sonic energy also derives from the interaction of the güiro and the maracas with the congas as well as the campana and the contra-campana. While the congas mainly articulated muffled subdivisions which were hard to distinguish during the live performance, except for the open strokes on the last two quaver in every bar, the campana and the contracampana propelled the song with new energies through their syncopations and subdivisions. These patterns supplied the rhythmic framework within which the very syncopated rhythmic layers of the interlocking bass and piano tumbaos operated, especially surrounding the fourth beat of the bar. At the same time, the bass tumbao continued to supply the rhythmic gravity established during the introduction surrounding beats 2 -and, 3, and 4, while also playing syncopated variations (b. 5).

Importantly, the piano tumbao also took on a rhythmic life on its own by introducing a sonic distinction between two pitches as Tony Rodriguez began to alternate between doubled and tripled octaves (see transcribed piano tumbao in Example 5). The tripled octaves repeated and varied a riff which was almost a 'signature hook ${ }^{\prime 84}$ for the montuno, while the doubled octaves presented as complementary ghost notes which enriched that hook. By constantly changing the relationship between the tripled and doubled octaves, Rodriguez fuelled the groove with new energy by 'repeating with a difference'. ${ }^{85}$ He provided a sense of rhythmic coherence and elaboration while allowing the participating audience to engage with the groove at a deeper level of embodied engagement.

When I asked my informant María, a timba aficionado with no musical training, about how Havana D'Primera's music grooved, she pointed to the relationship between the piano and bass tumbaos:

That timba is more violent, more more takakatakataka. It is more attacking . . they incorporate more instruments and give it more tastiness (sabrosura) ... more ritmo and also more melody [from the piano tumbao]. But if you take out the bass, it's not the same anymore. You know that the bass is kin-kin-kon [sings a bass line; see transcription in Example 6].

Bass Guitar

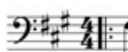

Example 6 Transcription of the bass line María sang. Pitches are tentative, the important information is in the rhythmic placement.

That groove (ritmo) is very contagious and friendly (acogedor y pegajoso). It is contagious because the people that said just a minute ago that they don't know how to dance and mark the rhythm, then the timba starts and they move from one side to

83 Conversation with Rodriguez in Romerío, Havana, September 2010.

84 Mark Spicer, '(Ac)Cumulative Form in Pop-Rock Music', Twentieth-Century Music 1/1 (2004), 38. For work on how such hooks work in Cuban timba piano, see Fiol, 'Cubaneo in Latin Piano', and Fiol, 'Grooves and Waves'; and Kevin Moore, Beyond Salsa for Ensemble (Santa Cruz, CA: Author, 2012). 
the other. They enjoy it ( $p a$ aquí, pa allá). Haven't you seen this, how the people enjoy moving from here to there? And you say, 'Goddamn!' (Coño! $)^{86}$

While 'María' had no formal music education and could not read music, she had no doubts about what types of musical sounds produced the pleasurable timba groove, and they started with the piano and bass tumbaos. Her conviction in this regard is why detailed music transcriptions and analyses should not be viewed as exclusively formalist representations detached from the embodied social experience which they represent. Instead the transcribed tumbaos are better understood as musical actants that did important social work by releasing embodied sensations that allowed people to be together in that particular way, musically, socially, and politically. It was thanks to such musical actants, and many others, that sounds and bodies together made audible a political coro that encouraged young Cubans to leave the country in search of a better future. No matter the costs. But it was not a political argument. It was a sung argument that grooved. The deeper we got into those montuno grooves the stronger we felt that 'sonic rum' Ortiz talked about as new levels of 'the musicality of the Cuban people ${ }^{87}$ manifested socially through rhythmic interactions and intensities.

\section{Intensifying politics by twisting the groove}

After the montuno groove had repeated its alternating coros, guías, and smaller improvisations for almost ten minutes, there was a musical change. It started in the bass, as Yandy González switched from the established tumbao to a new bass line which was at once more syncopated and more laid-back, with fewer onsets per bar. These open rhythmic spaces were filled with alternating breaks and improvisations in the percussion section and a more syncopated piano tumbao. In this context, a catchy new coro allowed the event participants to partake in the musical events. While it was not possible to transcribe these new musical details ethnographically in real time at Casa de la Música, the transcription in Example 7 of the recorded version of the song, read in tandem with my fieldnotes from the concert, allows us to identify some of the musical structures which enabled those pleasures and politics to interact in affective experience.

The upward chromatic movement in the bass line destabilized the $\mathrm{F} \sharp$ minor tonality and enabled new energies to surge forward, including the interlocking piano tumbao's syncopated configurations, which played with established rhythmic expectations produced by the initial piano tumbao. In the first two bars of the new coro (bb. 1-2 in the transcription), pianist Tony Rodriguez introduced a small variation upon the already established piano tumbao by playing an interval of a third on the 1-and which anticipates the claved second beat in the first bar (compare the first bar of the piano in Example 7 with the second bar of the piano in Example 5). Still, the last three accents in the bar recalled the shape of the earlier tumbao figure (compare the rhythmic structures of the three last accents in the piano in b. 1 of Example 7 and b. 2 of Example 5). Then, in the second bar, he changed the established rhythmic and

86 Conversation with María, Havana, October 2010.

87 Ortiz, La africanía de la música folklórica cubana, 13. 

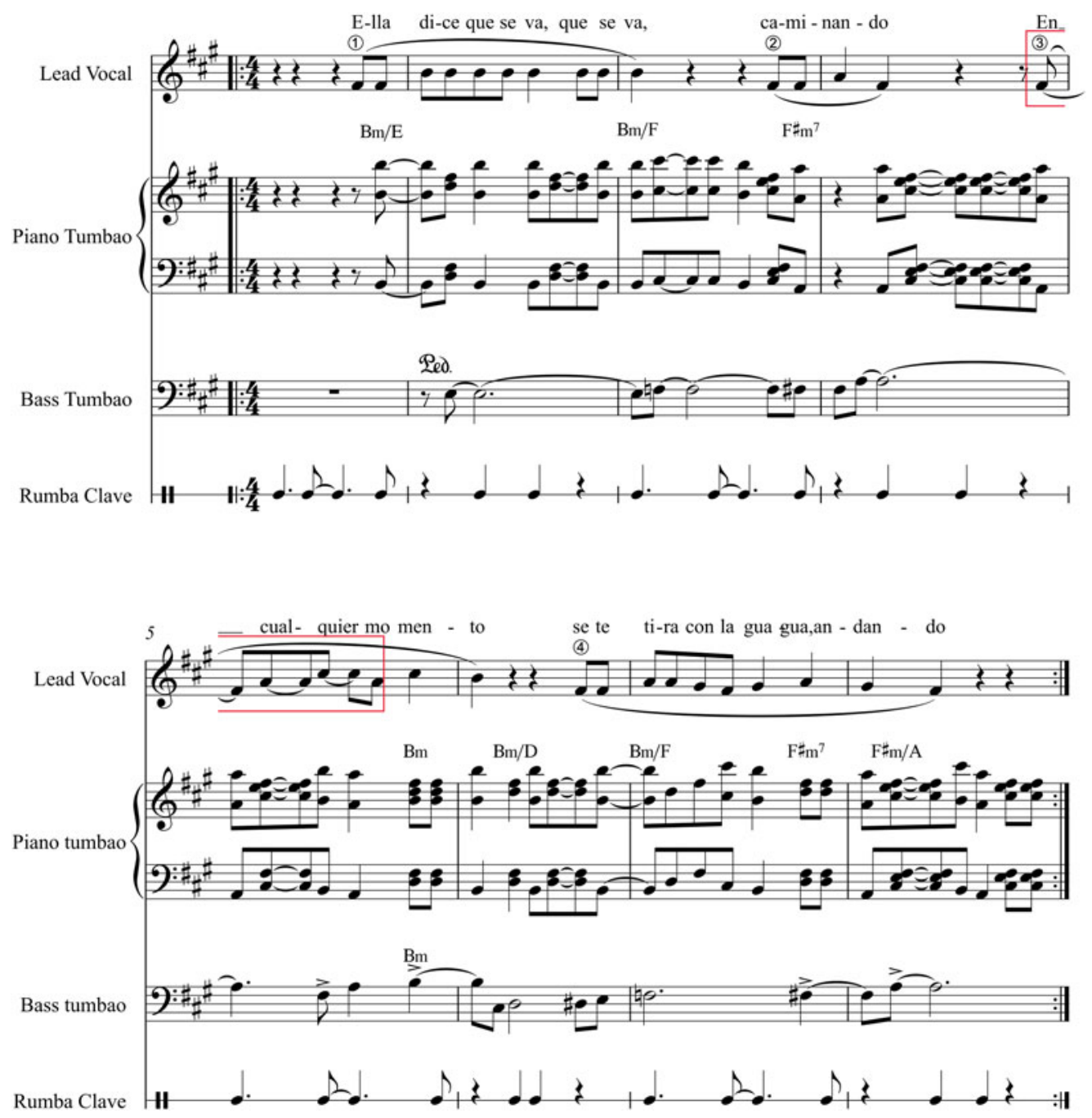

Example 7 Transcription of the second coro in the context of a repeating montuno groove composed of interlocking rhythms played by piano, bass, campana, contra campana, güiro, maracas, and congas. The transcription is based upon a combination of fieldnotes from the concert and the passage 3:02-3:14 on the recorded version of 'Pasaporte'.

melodic structure of the sequence by moving upward from $B$ to $\mathrm{C} \#$ earlier than he had before (compare bb. 1-2 in Example 7 with bb. 2-3 in Example 5) while simultaneously spicing up the $\mathrm{C} \#$ by playing it twice instead of once, and in a syncopated fashion (compare b. 2 in Example 7 with b. 3 in Example 5). Most enriching of all was the subsequent rhythmic change in bar 3, when he broke up the established alternation between tripled octaves and minor intervals (compare b. 3 in Example 7 with b. 4 in Example 5) by instead playing a pair of syncopated minor intervals (see square in b. 3, Example 7). It is through such rhythmic displacements and developments that the piano tumbao worked as a musical actant at Casa de la Música to put people's hands in the air and to rotate their hips all the faster. 
Cuban master pianist César 'Pupy' Pedroso argues that the piano tumbao itself can incite any crowd:

The piano-tumbao is enough to make people dance. You just start playing and then everybody starts moving ... In fact, you don't need anything more. It is all you need. Haven't you seen how they do this? In that timba that you call it, a break, and the piano tumbao, and people go wild. That's where the secret of what you call the groove lies. ${ }^{88}$

In tandem with the bass and piano tumbaos and the other percussion rhythm layers, Abreu elaborated on that second coro both politically and musically by engaging in call-and-response with the audience in the fashion of guía singing. ${ }^{89}$ Part of the infectious energy of this gesture derived from the coro's melodic structure, which reshuffled the first five tones in that $\mathrm{F} \#$ minor scale in ways which sustained melodic coherence despite the bass tumbao's rhythmic and harmonic flux. Abreu also took full advantage of the percussive phrasing of the lyrics' consonants, particularly the words 'dice-que-se-va-que-se va' (b. 1 in Example 7) and the arpeggiated syncopation of 'en cualquier momento' (bb. 3-5 in Example 7). In all, these elements allowed the coro to engage the crowd both socially and musically in powerful ways at Casa de la Música that night, as described in my original field notes and a photo from the event (Figure 1):

Abreu's face expresses pure energy. Several times he points the microphone at the audience. The whole crowd is singing and moving. Many people start waving their hands in the air. Shoulders and hips are rotating faster and faster, accompanying the bass pedal. The bass pedal is backed up by breaks in percussion and more groove improvisation patterns in the piano tumbao, constantly twisting around the established piano tumbao rhythmically. The atmosphere is electric. The groove, the coro, and the interlocking tumbaos demand a total presence with all the senses in the groove-based music. ${ }^{90}$

To summarize, a number of musical actants were at work - socially, politically, and musically - as the performance's specific organizations of sounds formed a new community which, in the context of the event, challenged the established divisions of the Cuban police order through their shared sonic pleasures. The two coros during the montuno elaborated on the narrative in the song's verses by drawing attention to a range of social problems which, taken together, might encourage young Cubans to leave the country. In Cuba, the passport symbolizes the ability to travel freely to other countries - in 2010, however, at the time of the concert, a person also needed official 'permission to leave the country' (permiso de sal$i d a$ ), which was often difficult to obtain. The passport narrative also recalled to the audience

88 Interview with Pedroso, A la Mar, Havana, 18 December 2010.

89 In guía, the lead singer elaborates upon and dialogues with the melodic and textual material of the coro. See, for example, Fiol, 'Grooves and Waves'; Bøhler, 'Grooves, Pleasures and Politics in Salsa Cubana'.

90 Fieldnotes, 19 December 2010, Casa de la Música, Havana; Bøhler, 'Grooves, Pleasures and Politics in Salsa Cubana', 329. 


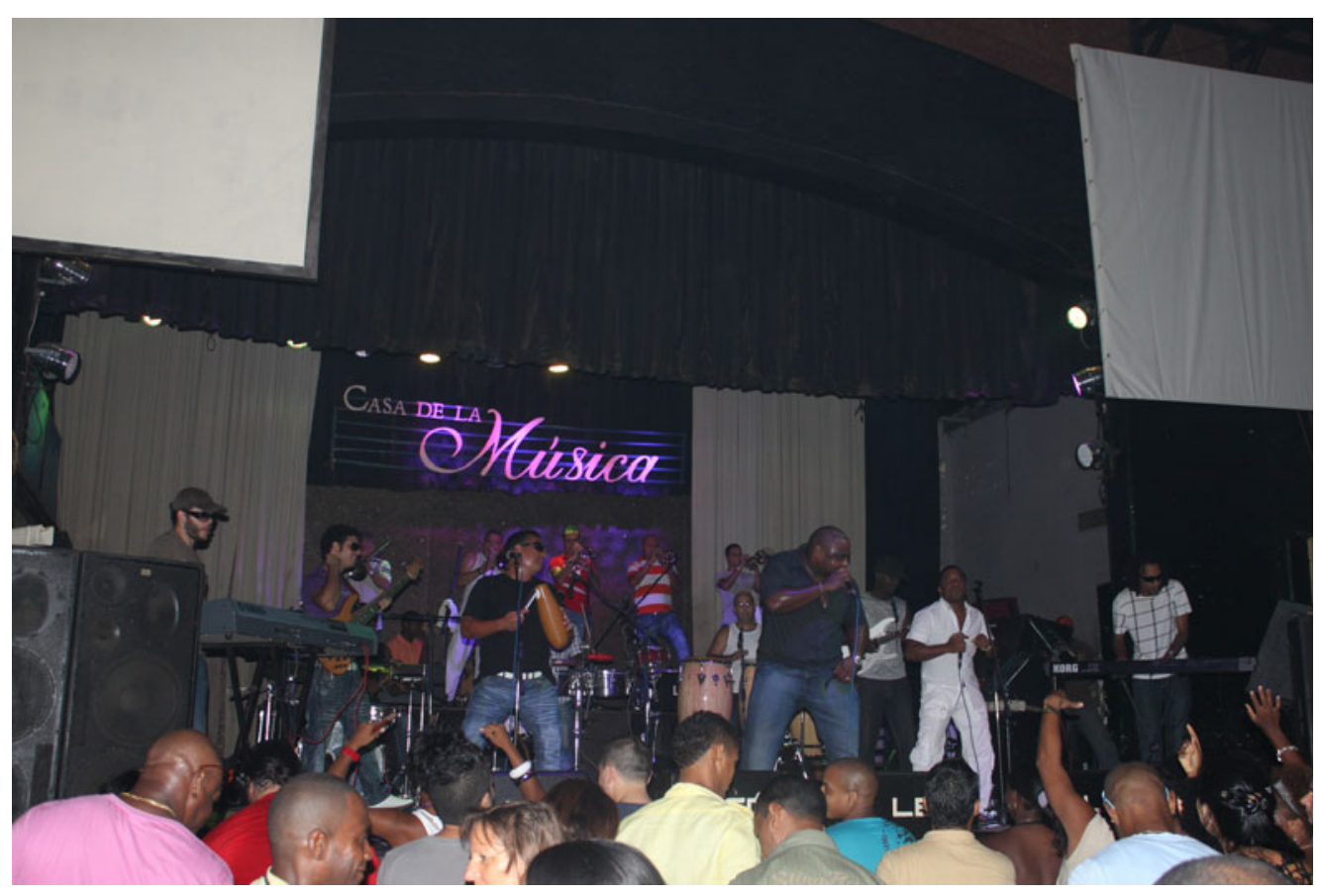

Figure 1 Photo from the event taken by the author with permission from Havana D'Primera.

their compatriots who live abroad (mainly the United States), who were not allowed to return to Cuba because the Cuban government considered their passports to be invalid. ${ }^{91}$ When I asked Alexander Abreu to elaborate on why his music was organized in that particular way, during an interview after the concert he elaborated on the relationship between social and rhythmic organization in Cuba:

Abreu: Here in Cuba we try to organise the beauty of our grooves [ritmos] so that they are not chaotic . . . but pleasurable, joyful, and full of energy. . . . [The groove] is like the energy of el Cubano, it goes very high up, and also all the way down.... It is because, let me think - how do I put this - el Cubano is a picaroon (picaro), very alive, he has a lot of spark and intensity (chispa), and these things give life to what is going on in the music. ...

Bøhler: Can you tell me more about that feeling, that temperament, as you called it, and its relationship with that Cuban identity?

Abreu: The important thing is to transmit that energy. But it has to be the energy of $e l$ Cubano, in the polyrhythm, in the groove, in the peace, in the aggressivity. It is how

91 This has changed in recent years. See, for example, Viviana Andreescu and Dan M. Tsataros, 'Immigration Policies and Criminal Justice Outcomes: The Case of Cuban Immigrants in United States', Journal of Identity and Migration Studies 13/2 (2019); Yulianela Pérez García, 'State and Migration: The Reflection of the Policies in the External Mobility of Cubans', Politica, Globalidad y Ciudadanía 6/11 (2020). 
we express things, in the rhythmic patterns, the piano tumbaos and the bass tumbaos, los coros. Everything has to be picante. Do you understand what I mean? ... Musically spicy. All this has to be part of it, that's the thing. A lot of people don't understand this. And yet this is what a lot of people like about our music. . . Energy. A lot of energy . . . and it is [the] live [performance] where this happens. Live, people are enjoying all these musical gestures, they are dancing, looking at each other, communicating, sweating. And this is what gives the energy, force - it puts everything together, almost like a different kind of music. . . People have to listen to it live because it is live where the real music is. ${ }^{92}$ (Interview with Abreu, Havana, 14 December 2010)

For Abreu, then, the musical energy at Casa de la Música was deeply Cuban, or aligned with el Cubano - to him, the type of person who appreciated and thrived upon polyrhythmic interactions and energy. Abreu's objectification of el Cubano was a product of my presence as a white male European musicologist interviewing him about his music, but it was also a result of Abreu's musical background and experiences, including his work within the Cuban timba scene as a trumpeter since the 1990s and his six years of work as a timba musician in Copenhagen, where he found that his spicy rhythms received a somewhat different reception. ${ }^{93}$ But in Havana, and more broadly, in Cuba, his music worked. That is part of the reason why Abreu decided to go back, start Havana D'Primera and compose and performs songs such as 'Pasaporte'. Perhaps Abreu's interpretation of el Cubano's musical preferences and sensibilities was both a product of my presence as a foreign interviewer and of his own experience with Cuban timba abroad and home? We don't know. However, we do know that 'Pasaporte' grooved politically and musically in powerful ways at Casa de la Música on Tuesday 7 December 2010, between 6 and 9 pm thanks to complex interactions between sounds and people.

92 Interview with Abreu, Havana, 14 December 2010. Translated by the author. Original: 'Abreu: Aquí en Cuba estamos ahora tratando de organizar la sabiduría en nuestros ritmos para que no sean caóticos. . . Pa' que sean sabrosos, rico, con energía... Es como la energía del Cubano es así, sube y baja mucho.... Es porque, espérate - como te explico - El Cubano es muy pícaro, muy vivo, tiene mucha chispa, entonces esas cosas son las que dan vida a lo que esta pasando no. ... Bøhler: Puedes explicarme un poco sobre ese sentimiento, o temperamento que lo llamas, y la relación entre eso y el Cubano? Abreu: Lo importante es transmitir energía, ahora, tiene que haber la energía de un cubano . . . en la poliritmia, el groove, el ritmo, la paz, y la agresividad, la forma de expresar las cosas, las marchas, las tumbaos, los coros. Que todo sea picante, ¿entiendes? ... ¿Entiendes? Musicalmente picante. Todo eso tiene que ser parte de la música. Y eso es lo que mucha gente no entiende. Pero e fundamental para nuestra música. Es lo que la gente le gusta . . . la energía. Mucha energía. . . Pero para entender eso tiene que entender la música en vivo. Es en vivo donde todo eso manifiesta. En vivo mucha gente están gozando todos esos gestos musicales, bailando, mirándose uno al otro, comunicando, sudando. Y eso es lo que da la energía, fuerza, que ponga todo en su lugar. En vivo es como otra música. La gente tiene que escucharlo en vivo porque en vivo es donde está la música.'

93 Before he started Havana D'Primera, Abreu was a world-famous lead trumpet player in a number of timba orchestras, including Paulito FG y su Elite, Jose Manuel Ceruto, and Issac Delgado. He also played in the jazz fusion band Irakere and in the Danish salsa orchestra Danson. See https://worldmusiccentral.org/2019/11/16/artist-profiles-alexanderabreu/. 


\section{From grooves to everyday speech}

As 'Pasaporte' grew in popularity, it also influenced everyday speech on the island. Both during fieldwork in December 2010 and when I revisited Cuba in 2012, 2015, and 2018, I overheard Cubans using fragments from the song in different conversations to make sense of everyday life. The most common of these was the phrase 'surviving the crisis' (sobreviviendo a la crisis). These words were both a reply to different versions of 'what's up', 94 marking the entry point of everyday talk, and articulations of social and political critique as 'surviving the crisis' made allusions to Rancierian expressions of 'dissensus' because they were linked to a broader notion of la lucha ('the struggle') as a larger discursive trope. ${ }^{95}$ In a Cuban context la lucha is both charged with revolutionary values and critiques of these values. ${ }^{96}$ With regards to the former la lucha is mapped onto a revolutionary struggle against colonialism, imperialism, and more recently, a global neo-liberal order. Being a luchadora or luchador ('struggler'), or simply estoy en la lucha ('being in the struggle'), in this sense, is an expression of revolutionary commitment and dedication. However, understanding la lucha as dissensus is a resignification that underscores a hidden battle between the Cuban people and the government. In this sense being in la lucha, or being a luchador or luchadora, can be used to justify seemingly counter-revolutionary actions such as engaging in prostitution, the black market or stealing from the state. A number of sexual workers ${ }^{97} \mathrm{I}$ interviewed in Havana referred to themselves as luchadoras and justified their decisions and actions because Cuba, for them, was in crisis. They were only 'surviving the crisis' and trying to find means to leave the country. ${ }^{98}$ They all had 'passport faces' and loved the song because they identified with it, both musically and politically. Of course, whether revolutionary or counter-

94 In Cuban street language, this often took the shape of ¿Qué bolá?, ¿Qué bolero?, and ¿cómo estás?

95 My understanding of discursive tropes is informed by Michel Foucault, The Archeology of Knowledge (London: Routledge, 1989), 98-102. It also builds on interpretations of this perspective in ethnomusicological research by Juan Diego Diaz Meneses, Africanness in Action: Essentialism in the Musical Imagination of Africa in Bahia, Brazil (New York: Oxford University Press, forthcoming), and Bøhler, 'Grooves, Pleasures and Politics', 214-18.

96 For interpretations of la lucha as a form of revolutionary commitment, see, for example, Julia Sweig, Inside the Cuban Revolution (Cambridge, MA: Harvard University Press, 2009), 1-24; and Alejandro De la Fuente, A Nation for All: Race, Inequality, and Politics in Twentieth-Century Cuba (Chapel Hill: University of North Carolina Press, 2001), 259-317. For interpretations of la lucha as a critique of revolutionary values, see, for example, Baker, Buena Vista in the Club; Hernández-Reguant, ed. Cuba in the Special Period and Ideology in the 1990s; and Perna, Timba.

97 Locally, many of these sexual workers referred to themselves and were understood by others as jineteras, which is a particular Cuban term for being a prostitute/engaging in sexual work. While the term jinetera is complex and may have different significations depending on the context, one unifying meaning across these contexts is that the term refers to a transaction between two or more people in the informal economy and that sexual work is only one, among different potential things, that may be involved. However, as underscored by increased scholarship on jinetera/-o and jineterismo in Cuba, sexual work remains the central theme of much jinterismo in practice. See, for example, Coco Fusco 'Hustling for Dollars: Jineterismo in Cuba', in Global Sex Workers, ed. Kamala Kempadoo and Jo Doezem (London: Routledge, 2018); Ana Alcázar Campos, “Jineterismo”: ¿turismo sexual o uso táctico del sexo?', Revista de Antropología Social 19 (2010); Mette Louise Berg, 'Tourism and the Revolutionary New Man: The Specter of Jineterismo in Late "Special Period" Cuba', Focaal 43 (2004); and Alyssa Garcia, 'Continuous Moral Economies: The State Regulation of Bodies and Sex Work in Cuba', Sexualities 13/2 (2010).

98 Either financially by making enough money to leave the country as this became possible due to changes in the Cuban migration law in 2012, or by marrying a foreigner and in some cases finding 'true love' thus complicating established 
revolutionary significations of la lucha are alluded to depends on the context. However, in conversations where Cubans replied 'surviving the crisis', those words seldom referred to the crisis of neo-liberalism, imperialisms, or global capitalism. Instead, the crisis was shared and heterogeneous but also local and subjective. In fact, a number of different crisis potentially mapped onto each other as the crisis in the Cuban transportation system, the housing crisis, and difficulties in finding basic food supplies fed into a broader crisis of political representation as hinted upon in Abreu's singing of los problemas and la censura. Listening carefully to the song suggested that migration provided a solution to these problems as 'Pasaporte' repeated "She is there, with her passport face, surviving the crisis, surviving getting beaten."

\section{Conclusion}

What if these political arguments had no musical sound and all we had was a piece of paper with the words of 'Pasaporte' on it? Would the impact of those words on individuals and political communities be the same? Would the politics of those words read the same? Based on my fieldwork, I would say no. Those words would still represent a political act, but nobody could dance to them, extract pleasures from their rhythms and melodies, sing along to their arguments, bring those arguments to parties, or listen to those arguments over and over again on loudspeakers or through headphones. They would not influence people in the same way, because Cuban politics, by itself, is nowhere near as popular as Cuban music. While a growing number of Cubans have grown sceptical about and even try to avoid la política, ${ }^{99}$ many people love timba and popular songs such as 'Pasaporte' - 'social chronicles' which, potentially, shape the values, preferences, and visions of people to a much greater extent than the talk of politicians, often dismissed as politiquería. ${ }^{100}$ Shared sonic pleasures are political experiences which question 'what is common to the [Cuban] community' and enable new forms of critique, as illustrated in the preceding analysis. Instead of dismissing the politics in musical texts to instead focus on 'a wide range of social and technological mediations ${ }^{101}$ or music's broader contextualizations, ${ }^{102}$ I argued that it is important to rethink the relationship between the popular and the political musically - as interactions between sounds and people.

It is perhaps better understood in light of Antoine Hennion's argument that important mediations can be found between musical sounds and listening subjects in experience; ${ }^{103}$

pre-understandings of prostitution/sexual work. However, the relationship between sex and money, and more broadly between love and economic wealth in Cuba, is complex and beyond the focus of the present article.

99 See Kjetil Klette Bøhler, 'Musical Politics in the Cuban Police Order', in Rancière and Music, ed. Cachopo, Nickleson, and Stover, 187.

100 Politiquería captures the notion that la politica and political discussions were dangerous, restricted spaces reserved for politicians and the party, not the people. See Bøhler, 'Musical Politics in the Cuban Police Order', 181-2.

101 Negus, Popular Music in Theory, 192.

102 Frith, Performing Rites, 26.

103 See Hennion, The Passion for Music. For related arguments see, for example, Born and Barry, 'Music, Mediation Theories and Actor-Network Theory'. 
or Barry Shank's argument that musical beauty has a particular political force; ${ }^{104}$ or Jocelyne Guilbault's interpretation of musical pleasures as expressions of affective politics. ${ }^{105}$ If it is true that music exists first and foremost in experience, we should study interactions between the musical and the political at this level and explore how catchy melodies and engaging grooves afford new sonic spaces of political participation and critique. The stable subdivisions streaming from güiro and maracas together with syncopations emerging between interlocking bass and piano tumbaos that dialogued with a dense polyrhythmic fabric held together by a two-three rumba clave and call-and-response singing allowed participating listeners to experience politics in new ways that night at Casa de la Música. This is not a politics located outside the musical but a 'micro politics of affect ${ }^{\text {'106 }}$ which is defined by the multiple ways in which people are impacted by sounds and other listeners as they partake musically when singing and dancing political statements.

In terms of social and political theory, the present study contributes to growing scholarship on affective communities, affective politics, and the politics of aesthetic experiences by reinterpreting musical structures and field notes as articulations of relational agency through the concept of musical actants read in light of Jacques Rancière's work on the politics of aesthetics. ${ }^{107}$ This notion of musical actants invites us to move beyond political theories modelled on a priori distinctions between 'surface and substratum '108 by instead listening musically to how politics become audible through particular musical structures. By specifying the temporal and sonic organizations of musical sounds, the present study adds to existing music scholarship on affective politics by integrating ethnography with in-depth musical analysis. More importantly, by interpreting such musical and ethnographic data in light of Rancière's aesthetic rethinking of politics coupled with Latour's redefinition of agency as relational, the article moves beyond binaries between the musicological and the anthropological and stimulates new interdisciplinary conversations between music theory, (ethno)-musicology, music anthropology, aesthetics, and political theory. In short, more conceptual and empirical work is needed on the affective and musical articulations of politics as songs shape political subjectivities and movements in complex ways. ${ }^{109}$

104 Shank, The Political Force of Musical Beauty.

105 Guilbault, 'Party Music, Affect and the Politics of Modernity'.

106 Dennis Büscher-Ulbrich, Dissensual Operations: Bruce Andrews and the Problem of Political Subjectivity in Post-Avant-Garde Aesthetic Politics and Praxis (DPhil., University of Hamburg, 2016), 20.

107 Related studies addressing affective communities include Hutchison, Affective Communities in World Politics; Martha C. Nussbaum, Political Emotions (Cambridge, MA: Harvard University Press, 2013); those addressing affective politics include, among others, Massumi, Politics of Affect; Nigel Thrift, Non-Representational Theory: Space, Politics, (New York: Routledge, 2008); and Ruth Leys, 'The Turn to Affect: A Critique', Critical inquiry 37/3 (2011). Those addressing the politics of aesthetic experience include Franklin Rudolf Ankersmit, Aesthetic Politics: Political Philosophy Beyond Fact and Value (Palo Alto, CA: Stanford University Press, 1996), and Political Representation (Palo Alto, CA: Stanford University Press, 2002).

108 Rancière, The Politics of Aesthetics, 49.

109 The ways in which popular music may channel new forms of political critique and create novel forms of political awareness through affective and aesthetic means are not exclusive to Cuba and a number of authors have elaborated on how popular music have done similar work elsewhere. In addition to the work already quoted in this article, see, 
In one sense, politics changed that Tuesday night in Havana in 2010 because 'Pasaporte' redistributed the sensible in Cuba by changing established 'divisions of the audible ${ }^{\text {,10 }}$ through musical pleasure. These pleasures allowed words and arguments to be repeated and shared the following days, weeks, and years, as Havana D'Primera consolidated itself as one of Cuba's most popular timba bands. Owing to this 'Pasaporte', other songs by Havana D'Primera and other artists have continued to do important political work musically in Cuba as sounds and people have interacted affectively in new ways. ${ }^{111}$ However, that work is beyond the scope of the present study and should rather inspire future research on musical politics in Cuba and elsewhere.

\section{Bibliography}

Abe, Marié. Resonances of Chindon-ya: Sounding Space and Sociality in Contemporary Japan. Middletown: Wesleyan University Press, 2018.

Acosta, Leonardo. 'On Generic Complexes and Other Topics in Cuban Popular Music', trans. Daniel Whitesell and Raúl Fernández, Journal of Popular Music Studies, 17/3 (2005), 227-54.

Akrich, Madeleine. 'The De-scription of Technical Objects', in Shaping Technology/Building Society: Studies in Sociotechnical Change, ed. Wiebe E. Bijker and John Law. Cambridge, MA: MIT Press, 1992. 205-24.

Alcázar Campos, Ana. “Jineterismo”: ¿ ¿turismo sexual o uso táctico del sexo?', Revista de Antropología Social 19 (2010), 307-35.

Alén, Olavo. De lo afrocubano a la salsa. Havana: Ediciones Artes, 1994.

. Géneros de la música cubana. Havana: Editorial Pueblo y Educación, 1977.

.'Rhythm as Duration of Sounds in Tumba Francesa', Ethnomusicology 39/1 (1995), 55-71.

Andreescu, Viviana and Dan M. Tsataros. 'Immigration Policies and Criminal Justice Outcomes: The Case of Cuban Immigrants in United States', Journal of Identity and Migration Studies 13/2 (2019), 5-25.

Ankersmit, Franklin Rudolf. Aesthetic Politics: Political Philosophy Beyond Fact and Value. Palo Alto, CA: Stanford University Press, 1996.

- Political Representation. Palo Alto, CA: Stanford University Press, 2002.

Arom, Simha. African Polyphony and Polyrhythm: Musical Structure and Methodology. Cambridge: Cambridge University Press, 2004.

Askew, Kelly. Performing the Nation: Swahili Music and Cultural Politics in Tanzania. Chicago: University of Chicago Press, 2002.

Avelar, Idelber and Christopher Dunn. Brazilian Popular Music and Citizenship. Durham: Duke University Press, 2011.

Baker, Geoffrey. Buena Vista in the Club: Rap, Reggaetón, and Revolution in Havana. Durham: Duke University Press, 2011.

—. 'Cuba Rebelión: Underground Music in Havana', Latin American Music Review 32/1 (2011), 1-38.

—. '¡Hip Hop, Revolución! Nationalizing Rap in Cuba', Ethnomusicology 49/3 (2005), 368-402.

_. 'Mala Bizta Sochal Klu: Underground, Alternative and Commercial in Havana Hip Hop', Popular Music 31/1 (2012), 1-24.

Bargetz, Brigitte. 'The Distribution of Emotions: Affective Politics of Emancipation', Hypatia 30/3 (2015), 580-96. Bates, Eliot. 'The Social Life of Musical Instruments', Ethnomusicology 56/3 (2012), 363-95.

for example, Alexei Yurchak, Everything was Forever, Until It was No More: The Last Soviet Generation (Princeton: Princeton University Press, 2006), 207-82; Idelber Avelar and Christopher Dunn, eds., Brazilian Popular Music and Citizenship (Durham: Duke University Press, 2011); Marcelo Ridenti, Em busca do povo brasileiro (São Paulo: Editora Unesp, 2016); and Marcos Napolitano, 'A arte engajada e seus públicos (1955/1968)', Revista estudos históricos 2/28 (2001).

110 Rancière, Politics of Aesthetics, 89-90.

111 The political work made audible through 'Pasaporte's musical grooves can be situated within a broader musicalpolitical tradition in Cuba starting in the 1990s timba through hits such as NG la Banda's 'Bruja' and Charanga Habanera's 'Temba'; see Perna, Timba, 192-230. 
Berg, Mette Louise. 'Tourism and the Revolutionary New Man: The Specter of Jineterismo in Late "Special Period" Cuba', Focaal 43 (2004), 46-56.

Blacking, John. How Musical is Man? Seattle: University of Washington Press, 2000.

Born, Georgina. 'On Musical Mediation: Ontology, Technology and Creativity', Twentieth- Century Music 2/1 (2005), 7-36.

Born, Georgina and Andrew Barry. 'Music, Mediation Theories and Actor-Network Theory', Contemporary Music Review, 37/5-6 (2018), 443-487.

Boudreault-Fournier, Alexandrine. 'Positioning the New Reggaetón Stars in Cuba: From Home-Based Recording Studios to Alternative Narratives', The Journal of Latin American and Caribbean Anthropology 13/2 (2008), $336-60$.

Brackett, David. 'The Politics and Practice of “Crossover” in American Popular Music, 1963 to 1965', The Musical Quarterly 78/4 (1994), 774-97.

Brotherton, P. Sean. Revolutionary Medicine: Health and the Body in Post-Soviet Cuba. Durham: Duke University Press, 2012.

Butler, Mark J. Unlocking the Groove: Rhythm, Meter, and Musical Design in Electronic Dance Music. Bloomington: Indiana University Press, 2006.

Büscher-Ulbrich, Dennis. 'Dissensual Operations: Bruce Andrews and the Problem of Political Subjectivity in Post-Avant-Garde Aesthetic Politics and Praxis'. DPhil diss., University of Hamburg, 2016.

Bøhler, Kjetil Klette. 'Groove Aesthetics in Afro-Cuban Jazz: Towards an Empirical Aesthetic Theory', Studia Musicologica Norvegica 39/1 (2013), 63-91.

_. 'Grooves, Pleasures and Politics in Salsa Cubana: The Musicality of Cuban Politics and the Politics of Salsa Cubana'. DPhil diss., University of Oslo, 2013.

- 'Musical Politics in the Cuban Police Order', in Rancière and Music, ed. João Pedro Cachopo, Patrick Nickleson, and Chris Stover. Edinburgh: Edinburgh University Press. 177-207.

—. 'Musikkens politiske kraft i det Revolusjonære Cuba', Studia Musicologica Norvegica 42/1 (2016), 52-74.

- "Somos la mezcla perfecta, la combinación más pura, cubanos, la más grande creación”: Grooves, Pleasures, and Politics in Today's Cuba', Latin American Music Review 37/2 (2016), 165-207.

- Theorizing Musical Politics through Case Studies: Feminist Grooves against the Temer Government in Today's Brazil', International Journal of Gender, Science and Technology 9/2 (2017). http://genderandset. open.ac.uk/index.php/genderandset/article/view/494/842 (accessed 2 January 2021).

Cachopo, João Pedro, Patrick Nickleson, and Chris Stover. Rancière and Music. Edinburgh: Edinburgh University Press, 2020

Casanella Cué, Liliana and Orestes Solís Yero. En defensa del texto. Santiago de Cuba: Editorial Oriente, 2004.

Chernoff, John Miller. African Rhythm and African Sensibility. Chicago: University of Chicago Press, 1979.

Chor, Ives. 'Microtiming and Rhythmic Structure in Clave-Based Music: A Quantitative Study', in Musical Rhythm in the Age of Digital Reproduction, ed. Anne Danielsen. New York: Routledge, 2016. 37-50.

Clarke, Eric F. 'The Impact of Recording on Listening', Twentieth-Century Music 4/1 (2007), 47-70.

- Ways of Listening: An Ecological Approach to the Perception of Musical Meaning. Oxford: Oxford University Press, 2005.

Danielsen, Anne. Presence and Pleasure: The Funk Grooves of James Brown and Parliament. Middletown, CT: Wesleyan University Press, 2006.

DeNora, Tia. Music in Everyday Life. Cambridge: Cambridge University Press, 2000.

Diaz Meneses, Juan Diego. Africanness in Action: Essentialism in the Musical Imagination of Africa in Bahia, Brazil. New York: Oxford University Press, forthcoming.

- 'Listening with the Body: An Aesthetics of Spirit Possession outside the Terreiro', Ethnomusicology 60/1 (2016), 89-124.

Drott, Eric. Music and the Elusive Revolution: Cultural Politics and Political Culture in France, 1968-1981. Berkeley: University of California Press, 2011.

Fernandes, Sujatha. 'Fear of a Black Nation: Local Rappers, Transnational Crossings, and State Power in Contemporary Cuba', Anthropological Quarterly 76/4 (2003), 575-608.

Fiol, Orlando Enrique. 'Cubaneo in Latin Piano: A Parametric Approach to Gesture, Texture, and Motivic Variation'. DPhil diss., University of Pennsylvania, 2018.

- 'Grooves and Waves: Cyclicity and Narrativity in Cuban Timba Piano', Latin American Music Review 33/1 (2012), 1-26.

Foucault, Michel. The Archeology of Knowledge. London: Routledge, 1989.

Frith, Simon. Performing Rites: On the Value of Popular Music. Oxford: Oxford University Press, 1998.

Fuente, Alejandro De la. A Nation for All: Race, Inequality, and Politics in Twentieth-Century Cuba. Chapel Hill: University of North Carolina Press, 2001. 
Fusco, Coco. 'Hustling for Dollars: Jineterismo in Cuba', in Global Sex Workers, ed. Kamala Kempadoo and Jo Doezem. London: Routledge, 2018. 151-66.

Fuson, Timothy Dale. 'Musicking Moves and Ritual Grooves across the Moroccan Gnawa Night'. DPhil diss., University of California, Berkeley, 2009.

Gámez Torres, Nora. 'Hearing the Change: Reggaeton and Emergent Values in Contemporary Cuba', Latin American Music Review 33/2 (2012), 227-60.

Garcia, Alyssa. 'Continuous Moral Economies: The State Regulation of Bodies and Sex Work in Cuba', Sexualities 13/2 (2010), 171-96.

García, David. Arsenio Rodríguez and the Transnational Flows of Latin Popular Music. Philadelphia: Temple University Press, 2006.

Garcia, Luis-Manuel. 'Feeling the Vibe: Sound, Vibration, and Affective Attunement in Electronic Dance Music Scenes', Ethnomusicology Forum (2020), 1-19.

García, Yulianela Pérez. 'State and Migration: The Reflection of the Policies in the External Mobility of Cubans', Política, Globalidad y Ciudadanía 6/11 (2020), 26-49.

Giddens, Anthony. The Constitution of Society: Outline of the Theory of Structuration. Berkeley: University of California Press, 1984.

Gil, Denise. Melancholic Modalities: Affect, Islam, and Turkish Classical Musicians. New York: Oxford University Press, 2017.

Gray, Ellen. Fado Resounding: Affective Politics and Urban Life. Durham: Duke University Press, 2013.

Grenet, Emilio. Popular Cuban Music. Habana: Editorial Letras Cubanas, 1939.

Guilbault, Jocelyne. Governing Sound: The Cultural Politics of Trinidad's Carnival Musics. Chicago: University of Chicago Press, 2007.

- 'Party Music, Affect and the Politics of Modernity', Journal of World Popular Music 6/2 (2019), 173-92.

Hagedorn, Katherine J. Divine Utterances: The Performance of Afro-Cuban Santería. Washington, DC: Smithsonian Institution Press, 2001.

Hebdige, Dick. Subculture: The Meaning of Style. New York: Routledge, 1979.

Henken, Ted. 'Balseros, Boteros, and El Bombo: Post-1994 Cuban Immigration to the United States and the Persistence of Special Treatment', Latino Studies 3/3 (2005), 393-416.

- 'Cuba's Digital Millennials: Independent Digital Media and Civil Society on the Island of the Disconnected', Social Research: An International Quarterly 84/2 (2017), 429-56.

Hennion, Antoine. 'Music and Mediation', in The Cultural Study of Music, ed. Martin Clayton, Trevor Herbert, and Richard Middleton. London: Routledge, 2012. 249-60.

Hennion, Antoine. The Passion for Music: A Sociology of Mediation. New York: Routledge, 2017.

Hennion, Antoine and Stephen Muecke. 'From ANT to Pragmatism: A Journey with Bruno Latour at the CSI', New Literary History 47/2 (2016), 289-308.

Hernández-Reguant, Ariana. Cuba in the Special Period and Ideology in the 1990s. Basingstoke: Palgrave Macmillan, 2009.

Hernández-Reguant, Ariana. 'Havana's Timba. A Macho Sound for Black Sex', in Globalization and Race: Transformations in the Cultural Production of Blackness, ed. Kamari Maxine Clarke and Deborah A. Thomas. Durham: Duke University Press, 2012. 249-79.

Herrera, Eduardo. 'Masculinity, Violence, and Deindividuation in Argentine Soccer Chants: The Sonic Potentials of Participatory Sounding-in-Synchrony', Ethnomusicology 62/3 (2018), 470-99.

Henriques, Julian. 'The Vibrations of Affect and Their Propagation on a Night Out on Kingston's Dancehall Scene', Body and Society 16/1 (2010), 57-89.

Hofman, Ana. 'The Affective Turn in Ethnomusicology', Muzikologija 18 (2015), 35-54.

- 'Disobedient: Activist Choirs, Radical Amateurism, and the Politics of the Past after Yugoslavia', Ethnomusicology 64/1 (2020), 89-109.

Hutchison, Emma. Affective Communities in World Politics. Cambridge: Cambridge University Press, 2016.

Hutchinson, Sydney. From Quebradita to Duranguense: Dance in Mexican American Youth Culture. Tucson: University of Arizona Press, 2007.

—, ed. Salsa World: A Global Dance in Local Contexts. Philadelphia: Temple University Press, 2015.

Juslin, Patrik N. and John Sloboda. Handbook of Music and Emotion: Theory, Research, Applications. New York: Oxford University Press, 2011.

Keil, Charles and Steven Feld. Music Grooves. Chicago: Chicago University Press.

Latour, Bruno. An Inquiry into Modes of Existence. Cambridge, MA: Harvard University Press, 2013.

. 'On Actor-Network Theory: A Few Clarifications Plus More Than a Few Complications', Soziale welt 47/4 (1996), 369-81.

- Reassembling the Social: A Guide to Actor-Network Theory. Cambridge: Cambridge University Press, 2005. 
—. 'Technology Is Society Made Durable', The Sociological Review 38/1 suppl. (1990), 103-31.

Lapidus, Benjamin. 'The Changüí Genre of Guantánamo, Cuba', Ethnomusicology 49/1 (2005), 49-74.

León, Argeliers. Del canto y el tiempo. Havana: Editorial Letras Cubanas, 1984.

Leys, Ruth. 'The Turn to Affect: A Critique', Critical Inquiry 37/3 (2011), 434-72.

López-Cano, Rubén. 'El chico duro de La Habana: Agresividad, desafío y cinismo en la timba cubana', Latin American Music Review, 28/1 (2007), 24-67.

_. 'Music and Post-Communist Subjectivities in Cuba', in Music and Youth Culture in Latin America: Identity Construction Processes from New York to Buenos Aires, ed. Pablo Vila. New York: Oxford University Press. 13256.

Madrid, Alejandro L. and Robin D. Moore. Danzón: Circum-Caribbean Dialogues in Music and Dance. Oxford: Oxford University Press, 2013.

Manabe, Noriko. The Revolution Will Not Be Televised: Protest Music after Fukushima. Oxford: Oxford University Press, 2015.

- 'We Gon' Be Alright? The Ambiguities of Kendrick Lamar's Protest Anthem', Music Theory Online 25/1 (2019). https://mtosmt.org/issues/mto.19.25.1/mto.19.25.1.manabe.pdf (accessed 2 January 2021).

- 'Women's March Colloquy_Chants of the Resistance: Flow, Memory, and Inclusivity', Music and Politics 13/1 (2019). https://quod.lib.umich.edu/m/mp/9460447.0013.105/-women-s-march-colloquy-chants-of-theresistance-flow-memory?rgn=main;view=fulltext (accessed 2 January 2021).

Manuel, Peter. 'The Anticipated Bass in Cuban Popular Music', Latin American Music Review 6/2 (1985), $249-61$.

Massumi, Brian. Politics of Affect. Cambridge: Polity Press, 2015.

Meintjes, Louise. 'Paul Simon's Graceland, South Africa, and the Mediation of Musical Meaning', Ethnomusicology 34/1 (1990), 37-73.

Middleton, Richard. Musical Belongings: Selected Essays. London: Ashgate, 2009.

Moore, Kevin. Beyond Salsa for Ensemble. Santa Cruz, CA: Author, 2012.

Moore, Robin. D. Music and Revolution: Cultural Change in Socialist Cuba. Berkeley: University of California Press, 2006.

'Transformations in Cuban Nueva Trova, 1965-95', Ethnomusicology 47/1 (2003), 1-41.

Morad, Moshe. Fiesta de diez pesos: Music and Gay Identity in Special Period Cuba. London Ashgate, 2015.

Napolitano, Marcos. 'A arte engajada e seus públicos (1955/1968)', Revista estudos históricos 2/28 (2001), $103-24$.

Nattiez, Jean-Jacques. Music and Discourse: Toward a Semiology of Music. Princeton: Princeton University Press, 1990.

Negus, Keith. Popular Music in Theory: An Introduction: Middletown: Wesleyan University Press, 1996.

Nketia, J. H. Kwabena. African Music in Ghana. Evanston, IL: Northwestern University Press, 1963.

Nussbaum, Martha C. Political Emotions. Cambridge, MA: Harvard University Press, 2013.

Orozco, Danilo. 'El son: ¿ritmo, baile o reflejo de la personalidad cultural cubana', in Musicología en Latinoamérica, ed. Zoila Gómez García. Havana: Editorial Arte y Literatura, 1984, 364-93.

Ortiz, Fernando. La africanía de la música folklorica cubana. Havana: Editorial Letras Cubanas, 2001.

- La clave. Havana: Editorial Letras Cubanas, 1995.

Pangle, Thomas. Aristotle's Teaching in the 'Politics'. Chicago: University of Chicago Press, 2013.

Peñalosa, David and Peter Greenwood. The Clave Matrix: Afro-Cuban Rhythm; Its Principles and African Origins. California: Bembe Books, 2009.

Perlman, Marc. 'The Social Meaning of Modal Practices: Status, Gender, History, and Pathet in Central Javanese Music', Ethnomusicology 42/1 (1998), 45-80.

Perna, Vincenzo. Timba: The Sound of the Cuban Crisis. London: Routledge, 2017.

Perry, Marc. Negro Soy Yo: Hip Hop and Racialized Citizenship in Neoliberal Cuba. Durham: Duke University Press, 2016.

Piekut, Benjamin. 'Actor-Networks in Music History: Clarifications and Critiques', Twentieth-Century Music 11/2 (2014), 191-215.

Putnam, Robert D. Bowling Alone: The Collapse and Revival of American Community. New York: Simon \& Schuster, 2000.

Radano, Ronald. 'Hot Fantasies: American Modernism and the Idea of Black Rhythm', in Music and the Racial Imagination, ed. Ronald Radano and Phillip Bohlman. Chicago: University of Chicago Press, 2000. 459-83.

Rancière, Jacques. 'Aesthetic Separation, Aesthetic Community: Scenes from the Aesthetic Regime of Art', Art and Research 2 (2008). www.artandresearch.org.uk/v2n1/ranciere.html (accessed 2 January 2021).

- Althusser's Lesson. London: Bloomsbury, 2011.

Dissensus: On Politics and Aesthetics. London: Bloomsbury, 2015.

- The Politics of Aesthetics. London: Bloomsbury, 2013.

Ridenti, Marcelo. Em busca do povo brasileiro. São Paulo: Editora Unesp, 2016. 
Roda, P. Allen. 'Ecology of the Global Tabla Industry', Ethnomusicology 59/2 (2015), 315-36.

Rosendahl, Mona. Inside the Revolution: Everyday Life in Socialist Cuba. Ithaca, NY: Cornell University Press, 1997.

Sakakeeny, Matt. Roll with It: Brass Bands in the Streets of New Orleans. Durham: Duke University Press, 2013.

Saunders, Tanya L. Cuban Underground Hip Hop: Black Thoughts, Black Revolution, Black Modernity. Austin: University of Texas Press, 2015.

Schaap, Andrew. 'Enacting the Right to Have Rights: Rancière's Critique of Hannah Arendt', European Journal of Political Theory 10 (2011), 22-45.

Shank, Barry. 'The Political Agency of Musical Beauty', American Quarterly 63/3 (2011), 831-55.

. The Political Force of Musical Beauty. Durham: Duke University Press, 2014.

Shelemay, Kay Kaufman. 'The Ethnomusicologist, Ethnographic Method, and the Transmission of Tradition', in Shadows in the Field: New Perspectives for Fieldwork in Ethnomusicology, ed. Gregory F. Barz and Timothy J. Cooley. Oxford: Oxford University Press, 1997. 189-204.

Shelley, Braxton D. 'Analyzing Gospel', Journal of American Musicological Society 72/1 (2019), 181-243.

Slater, Mark. 'Timbre and Non-radical Didacticism in the Streets' A Grand Don't Come for Free: A Poetic-Ecological Model. Music Analysis 30/2-3 (2011), 360-95.

Spicer, Mark. '(Ac)Cumulative Form in Pop-Rock Music', Twentieth-Century Music 1/1 (2004), $29-64$.

Spitzer, Michael. 'Mapping the Human Heart: A Holistic Analysis of Fear in Schubert', Music Analysis 29/1-3 (2010), 149-213.

-. Music and Politics. New York: John Wiley and Sons, 2013.

Solis, Gabriel. 'Thoughts on an Interdiscipline: Music Theory, Analysis, and Social Theory in Ethnomusicology', Ethnomusicology 56/3 (2012), 530-54.

Sonnenberg-Schrank, Björn. Actor-Network Theory at the Movies: Reassembling the Contemporary American Teen Film with Latour. Cham: Palgrave Macmillan, 2020.

Steingo, Gavin. Kwaito's Promise: Music and the Aesthetics of Freedom in South Africa. Chicago: University of Chicago Press, 2016.

Stover, Chris. 'A Theory of Flexible Rhythmic Spaces for Diasporic African Music'. DPhil diss., University of Washington, 2009.

Street, John. "'Fight the Power": The Politics of Music and the Music of Politics', Government and Opposition 38/1 (2003), 113-30.

- Music and Politics. New York: John Wiley and Sons, 2013.

Sweig, Julia. Inside the Cuban Revolution. Cambridge, MA: Harvard University Press, 2009.

Tatnall, Arthur and Bill Davey. 'The Internet of Things and Beyond: Rise of the Non-Human Actors', International Journal of Actor-Network Theory and Technological Innovation 7/4 (2015), 56-67.

Tausig, Benjamin. Bangkok Is Ringing: Sound, Protest, and Constraint. New York: Oxford University Press, 2019. Thrift, Nigel. Non-Representational Theory: Space, Politics, Affect. New York: Routledge, 2008.

Town, Sarah. “Timbeando en Nueva York”: Cuban Timba Takes Root Abroad', Ethnomusicology 63/1 (2019), $105-36$.

Turino, Thomas. Music as Social Life: The Politics of Participation. Chicago: University of Chicago Press, 2008.

Vaughan, Umi. Rebel Dance, Renegade Stance: Timba Music and Black Identity in Cuba. Michigan: University of Michigan Press, 2012.

Walser, Robert. 'The Body in the Music: Epistemology and Musical Semiotics'. Paper presented at the College Music Symposium, 1991. www.jstor.org/stable/40374121 (accessed 2 January 2021).

-. 'Popular Music Analysis: Ten Apothegms and Four Instances', in Analyzing Popular Music, ed. Allan Moore. Cambridge: Cambridge University Press, 2003. 16-38.

- 'Rhythm, Rhyme, and Rhetoric in the Music of Public Enemy', Ethnomusicology (1995), 193-217.

. Running with the Devil: Power, Gender, and Madness in Heavy Metal Music. Middletown, CT: Wesleyan University Press, 1993.

Washburne, Christopher. 'The Clave of Jazz: A Caribbean Contribution to the Rhythmic Foundation of an African-American Music', Black Music Research Journal 17 (1997), 59-80.

_. "Play It Con Filin!"': The Swing and Expression of Salsa', Latin American Music Review 19/2 (1998), 16085.

White, David. The Analysis of Music. Metuchen, NJ: Scarecrow Press, 1984.

Yurchak, Alexei. Everything was Forever, Until It was No More: The Last Soviet Generation. Princeton: Princeton University Press, 2006.

\section{Discography}

Alexander Abreu y Havana D’Primera. Pasaporte. London: Pafata Productions, 2012. 